\title{
Povezanost informacijske znanosti in psihologije na primeru paradoksa modrosti (1. del)
}

\author{
Connection between information science and psychology based on the \\ example of the paradox of wisdom, part 1
}

\section{Tvrtko-Matija Šercar ${ }^{1}$}

IZVLEČEK: Modrost je ena izmed številnih človekovih mentalnih sposobnosti. Mentalno vitalnost stereotipno povezujemo z mladostjo, mentalni upad pa s starostjo. Toda cena modrosti je tudi staranje. Povezanost nevrološkega upadanja (senilnost, demence) in razvoja modrosti med staranjem imenujemo paradoks modrosti. Razvoj interdisciplinarnih raziskav slabša predsodek o vodilni in sintetični vlogi filozofije. Informacijska znanost brez (nevro)psihologije sploh ni mogoča kot znanost, saj imajo informacijski pojavi, procesi in strukture trdne možganske (anatomsko-fiziološke) in psihične osnove. Nobena človekova mentalna sposobnost z zaznavanjem vred ni mogoča brez spomina in prepoznavanja vzorcev. Vzorec, shranjen v spominu možganov, deluje kot privlačevalec (atraktor), tako da tudi majhni deli mreže nevronov samodejno vzbudijo zadevno spominsko stanje v celoti.

KLJUČNE BESEDE: možgani, modrost, starost, prepoznavanje vzorcev, spomin, privlačevalec (atraktor)

ABSTRACT: Wisdom is one of many human mental capabilities. Mental vitality is stereotypically associated with youth and mental decline with old age. However, also aging is a price of wisdom. The connection between neurological decline (senility, dementias) and wisdom development during aging is referred to as the paradox of wisdom. The prejudice about the leading and synthetic role of philosophy is worsening the development of interdisciplinary research. Information science without (neuro)psychology is not even possible as science since information phenomena, processes and structures have solid brain (anatomical and physiological) and mental foundations. No human mental capability, including perception, is possible without memory and patterns recognitions. A pattern stored in the memory of the brain works as an attractor so that even small parts of neural network automatically fully revive the relevant memory condition.

KEYWORDS: brain, wisdom, old age, pattern recognition, memory, attractor

\section{Uvod v paradoks}

Modrost je ena izmed številnih človekovih mentalnih sposobnosti. Mentalno vitalnost stereotipno povezujemo z mladostjo, mentalni upad pa s starostjo. Toda cena modrosti je tudi staranje. Povezanost nevrološkega upadanja (senilnost, demence) in razvoja modrosti med staranjem imenujemo paradoks modrosti.

$\checkmark$ zadnjem času se veliko govori o potrebi po utemeljitvi informacijske znanosti $v$ filozofiji in po približevanju obeh znanosti. O tem sva več pisala s kolegom Brbretom (Šercar in Brbre, 2007). V članku, ki sva ga napisala z Valerijo Trojar (2009), sva predstavila model ameriške vojne mornarice, ki vključuje tudi teozofske elemente in modrost. Teozofija (božanska

\footnotetext{
${ }^{1}$ Dr. Tvrtko-Matija Šercar, upokojeni sodelavec IZUM, tvrtko.sercar@ext.izum.si.
} 
modrost) bi bila namreč filozofski nauk o božjem spoznanju po intuiciji ali po neposrednem, notranjem božjem razodetju.

Namen tega članka je pokazati povezanost informacijske znanosti in (nevro)psihologije predvsem na primeru individualne modrosti. Glavni trditvi sta:

- da razvoj interdisciplinarnih raziskav zmanjšuje potrebo po vodilni in sintetični vlogi filozofije ter

- da informacijska znanost brez (nevro)psihologije sploh ni mogoča kot znanost, saj imajo informacijski pojavi, procesi in strukture trdne možganske (anatomsko-fiziološke) in psihične osnove.

Na podlagi analize strokovne literature bomo v prvem delu izpostavili modrost z vidika religije, filozofije in nevropsihologije. Bolj podrobno bodo predstavljene anatomske, fiziološke in psihične osnove individualne modrosti (posameznikov), $v$ okviru katerih bo posebej izpostavljena povezava med spominom, prepoznavanjem vzorcev in modrostjo.

Čeprav se članek ukvarja z več rečmi, je njegov glavni namen na primeru modrosti pokazati materialne, biološke in psihološke osnove pojavov, ki so predmet sodobne informacijske znanosti, s tem pa pri mlajših kolegicah in kolegih spodbuditi zanimanje za nadaljnja premišljanja in empirične raziskave $v$ tej smeri.

\section{Modrost religije}

Individualno modrost poznajo vse velike religije in filozofije $v$ verski obliki (npr. taoizem, konfucianizem). Po Stari zavezi se modrost začenja s strahospoštovanjem do boga. Modrost je poosebljal kralj Salomon, sin Davidov. Dal mu jo je bog na njegovo izrecno prošnjo, in sicer $v$ tolikšni meri, da je bila njegova modrost večja od modrosti vseh ljudi na Vzhodu in od modrosti Egipta. Bog mu je dal tolikšno modrost zaradi tega, ker Salomon ni prosil za dolgo življenje ali bogastvo zase, ne za smrt sovražnikov, pač pa za sposobnost ločevanja dobrega in hudega pri krojenju pravice. Modrosti se je mogoče naučiti, zato so ljudje različnih nacionalnosti prihajali, da ga poslušajo.

Izvirno je človek pridobil sposobnost ločevanja dobrega in zlega proti božji volji. To je bil prvi človekov greh, pragreh. Bog je Adamu in Evi prepovedal jesti z drevesa spoznanja, kajti sicer bosta izgubila nesmrtnost. Po judovskem razumevanju je smrt naravni pojav in konec življenja, kazen za izvirni greh pa je delo (Mz 3,17). V krščanstvu je smrt kazen za pragreh.

Telo je grobnica duše kot božje emanacije. Dušo dobimo od boga in je neodvisna od telesa. Tako razumljena duša je osnova verovanja v življenje po smrti v judovskem šeolu, krščanskem peklu in raju ali rimskokatoliških vicah. Smrt je nujni pogoj za vstajenje in zapuščanje utelešenosti kot grešne materialnosti. Izhod je $v$ učenju apostola Pavla iz Tarza in cerkve kot izključne namestnice Boga na zemlji o odrešenju, ki predstavlja osnovo krščanstva.

Rimskokatoliška cerkev kot izključna pooblaščena posrednica med Bogom in ljudmi poda izhod iz grešnosti tega sveta. Jezus Kristus, ki ga je Bog posvetil in mazilil s svetim Duhom za poslanstvo odrešenika, je kot judovski mesija prišel na Zemljo, bil križan, umrl in tretji dan od mrtvih vstal, da bi s svojo žrtvijo kot Jagnje božje (lat. agnus dei) odrešil vse ljudi. Zaradi pomena Kristusove daritve za vse ljudi je simbol krščanstva križ. 
V Stari zavezi so modrosti izrecno posvečene knjige Job $(1,1-42,17)$, Pregovori $(1,1-31,31)$, Pridigar (Kohelet) $(1,1-12,14)$, Visoka pesem, Knjiga modrosti $(1,1-19,22)$ in Sirah $(1,1-52,16)$. Avtorstvo Knjige modrosti se pripisuje Salomonu. Vsebina je namenjena tistim judom, ki so pod vplivom helenizma začeli zapuščati vero svojih prednikov. Knjiga sestoji iz dveh delov različnih avtorjev. $\mathrm{V}$ prvem delu je prikazano, kaj vse verniki dosežejo, če živijo modro, $\mathrm{tj} . \mathrm{v}$ skladu z religioznimi predpisi, opisan je tudi način, kako se modrost lahko doseže (Modr1-9). Jasno so že izraženi eshatološke misli in napovedovanje konca sveta in sodbe. Potem bodo pravičniki živeli za vekomaj. $\mathrm{V}$ drugem delu so opisane prednosti modrega življenja v skladu $\mathrm{s}$ predpisi judovske vere (Modr. 10-19).

Pojem modrosti se pojavlja $v$ mnogih gnostičnih učenjih kot emanacija $v$ obliki ženske, ki po potrebi jemlje tudi telesno obliko ženske-matere. Vse sekte poznega gnosticizma postavljajo pojem modrosti na posebno mesto $v$ svoji teologiji, eshatologiji, soteriologiji in kozmogoniji. (Mandić, 1969). Po gnostiku Bazilidu sta modrost in moč starša drugih moči in angelov, ki skupaj ustvarjajo prvo nebo. Valentiniti štejejo modrost med šest ženskih bitij, ki skupaj $\mathrm{s}$ šestimi moškimi nastajajo s spajanjem božjih emanacij Človeka in Cerkve kot nadaljnja stopnja njihove materialnosti. V grški različici apokrifnih spisov sv. Tomaža stopa modrost v zakon z breznom in iz te njune povezave se Kristus rodi kot človek.

Nasproti temu se v gnostičnem spisu Pistis Sophia opisuje, kako Kristus po božji nalogi rešuje to "zvesto modrost«, ki se je zapletla z materijo. Delo v koptskem jeziku iz 3. stoletja je sestavljeno iz štirih delov: iz treh Rešiteljevih knjig in zadnjega dela, ki je brez naslova. Kristus podaja odgovore na šestinštirideset vprašanj, ki so mu jih zastavili njegovi učenci v dvanajstem letu po njegovem vstajenju. Devetintrideset izmed teh vprašanj je zastavila Marija Magdalena (iz Magdale). Vprašanja se nanašajo na sestavo in obliko nadzemeljskega sveta, na etične imperative za vernike, na misterije, ki jih je treba storiti za odpuščanje grehov (iz teh so nastali zakramenti kot skrivni obredi v krščanskih cerkvah), in na kazni, s katerimi so kaznovani grešniki na mestih, ki so $v$ temi, saj so najdlje od božanskega izvora svetlobe. Kristus poudarja, da se človeška duša lahko reši le na osnovi gnostičnega spoznanja.

Vendar tudi norost vabi na gostijo (Pregovori, 13-18). Znana je prilika o modrih in nespametnih devicah iz evangelija po Mateju (Mt 25, 1-13), v kateri slednje niso vzele zaloge olja, ki so ga potrebovale ob nočnem obisku ženina. Po hermenevtični razlagi Whitove (Vajt, 1985) je devica cerkev, svetilka Biblija, ženin Jezus Kristus, olje pa pravilno razumevanje namenov Božje besede svetega Duha, modre device je sveti Duh razsvetlil. Ženin prihaja z zamudo - gre za drugi advent. Medtem ko so nespametne device šle kupit olje, je Jezus Kristus prišel in modre device so šle z njim na svatbo. Svatba je zaveza. "Nespametne» cerkve ostanejo pred zaprtimi vrati. (Biblija.net, 2020)

Tudi verniki islama so prepričani, da le oni poznajo pravo modrost. Kot je zapisano $v$ dodanem uvodu k perzijskemu prevodu Pančatantre (Pet modrih), modrost sestoji iz osmih lastnosti. To so: (1) prijaznost; (2) spoznanje samega sebe in previdnosti; (3) spoštovanje oblasti; (4) védenje, kje in kdaj zaupati svojo skrivnost prijatelju; (5) sladkobesednost v družbi dvorjanov; (6) znati čuvati svojo in tujo skrivnost; (7) sposobnost upravljanja lastnega jezika in izogibanje rečem, zaradi katerih se lahko odgovarja; (8) v družbi ne govoriti o stvareh, o katerih nihče ne sprašuje (Behnud, 6. stoletje, 1953). 


\section{Modrost filozofije}

V grški mitologiji modrost pooseblja boginja Atena (pri Rimljanih Minerva). Modrost je hkrati namen filozofije. Tisti, ki razpravlja o modrosti brez jasnega filozofskega razumevanja, naj bi bil slepec, ki vodi slepca. Po Platonu je vrlina modrosti znanje o dobrem in pogum delati $v$ skladu z dobrim. Dobro je ideja, ki vključuje ideje dobre vladavine, ljubezni, prijateljstva, skupnosti in pravega odnosa do božanskega. Ljubezen do modrosti (filozofija) je pomembnejša kakor katera koli preizkušena potreba. Po Aristotelu, ki bolj poudarja kognitivni vidik modrosti, je modrost znanje vzrokov: zakaj stvari obstajajo na poseben način. Pod vplivom starih Grkov je modrost $v$ evropski kulturi povezana $s$ krepostjo. Tako je modrost po doktrini rimskokatoliške cerkve ena izmed štirih glavnih vrlin - poleg pravičnosti, trdnosti in zmernosti.

Po Platonovi teoriji človekovega padca so duh in mentalne sposobnosti funkcije duše. Preden je duša padla $v$ gmotni svet, je prebivala $v$ svetu idej najvišjega ranga resničnosti. Tam je neposredno zrla svet idej. Po padcu v gmotni svet duša pozabi znanje o svetu idej, spoznanje $\checkmark$ gmotnem svetu pa je spomin na tisto, kar je duša znala pred padcem. Spoznanje naj bi bilo izključni privilegij filozofov.

Znan je Platonov logofobični paradoks. V Platonovem dialogu Faidros (Phaidros, Phaedrus) Sokrat pravi: „Pisava bo v dušah tistih, ki jih naučijo, ustvarjala pozabo, ker ne bodo vadili spomina, ker bodo ljudje, ki se zanašajo na pisavo, izzivali spomin od zunaj s tujimi znaki, in se ne bodo spomnili notranjosti iz nje same. Nisi torej izumil zdravila za spomin, ampak za opominjanje, in učencem prinašaš navidezno, in ne resnične modrosti. Pisne besede nimajo drugačnega pomena kot tistega, da onega, ki zna, spomnijo na tisto, o čemur so pisane» (Platon, 1996). ${ }^{2}$

Že starogrški zdravnik, pisec in filozof Galen je vedel, da so duh in mentalne funkcije proizvodi možganov. Vendar zadeva ni tako preprosta, kot se zdi z (vulgarno) materialističnega stališča. Gre namreč za znani problem telo-duh (Popper, 1994; Šercar in Brbre, 2007).

Descartesov »jaz mislim, jaz sem « (Cogito ergo sum) je treba dopolniti z »jaz mislim nekaj« da bi sploh mislili, moramo misliti o nečem bodisi iz našega notranjega sveta bodisi iz zunanjega fizičnega sveta bodisi iz sveta kulture - in z »jaz povezujem« omenjene prepoznane in izkušene svetove. Sem ni predikat, kot se zdi z vidika vsakdanje zdravorazumske razlage, temveč absolutni subjekt in $s$ tem smo se rešili idealistične ontologije prosto lebdeče inteligence. V stavku »jaz sem« se s »sem « ne določa neka druga reč. »Jaz mislim nekaj« je v redu le pod pogojem, da je v tem »nekaj« neizgovorjena predpostavka sveta - jaz-sem-vsvetu. Heidegger (1997) bi rekel, da se v jaznem rekanju tubit izreka kot bit-v-svetu. Heidegger pokaže, da je sebstvo eksistencialno mogoče po samolastnosti biti tubiti kot skrbi. Skrb je bitna celost strukturne celote tubiti, smisel skrbi pa je časovnost.

Heideggerjeva samoumevnost biti in časa, časovnosti kot pogoja človekovega obstoja v svetu, smisla biti sploh, samega sveta in prostora v svetu (prostor je v svetu, in ne svet v prostoru) naj bi bila mogoča le kot rezultat fenomenološkega spoznanja predontoloških pogojev vsakega znanstvenega spoznavanja. Heideggerjeva bit in čas naj bi bila predonotološki pogoj psihičnih pojavov (z modrostjo vred), ki so posledica usodne povezanosti duha s telesom. Toda psihično, predvsem pa spomin, je kot predmet (nevro)psihologije, informacijske znanosti, informacijske

\footnotetext{
${ }^{2}$ Avtor prevedel iz hrvaščine.
} 
tehnologije in računalniških ved enakoizvorni pogoj razkritosti časovnosti (prihodnosti, vsakdanjosti in preteklosti), biti in zaobseženosti prostora v svetu. Ta krog je razumevanje samo. Opisani krog je v tem primeru razumevanje samo, in sicer kot domnevanje, in če tega kroga ne razumemo, nam ni dana niti možnost samega razumevanja. Platon ni bil daleč od resnice, ko je dejal, da je spoznavanje spominjanje, saj bomo videli, da zaznavanja brez spomina in prepoznavanja vzorcev ni.

Pri svoji vrnitvi k razvojni psihologiji pokažem, da je spomin kot mentalna sposobnost psihološki pogoj doživetja časovnosti in zgodovinskosti.

\section{Prirojeno ali pridobljeno?}

Debata o tem, kaj nam je prirojeno in kaj je pridobljeno, je zelo stara. Niti Locke ni bil daleč od resnice, ko je dejal, da je naš duh (možgani) neposredno po rojstvu tabula rasa (nepopisana pisalna deska), saj bomo videli, da je tabula rasa kot nevrofiziološka osnova mentalnih sposobnosti tisto, kar nam je prirojeno, medtem ko je vse drugo pridobljeno. Brez zaznavanja in shranjevanja zaznav, tj. brez informacij kot vsebine spomina in edine snovi, ki prihaja $v$ možgane prek čutil iz zunanjega sveta in našega telesa, tudi spomina ni.

Višje možganske živčne funkcije niso izključni rezultat možganov in se ne razvijejo same po sebi, saj zahtevajo interakcije z zunanjim fizičnim svetom, z drugimi, z našim notranjim svetom in telesom in s svetom kulture (Edelman in Tononi, 2000). Goldberg (2007) pokaže, kot bomo videli na primeru modrosti, da brez tabule rase kot možnosti oblikovanja atraktorjev ${ }^{3} v$ obliki nevronskih mrež, ki je prirojena materialna osnova spomina in prepoznavanja vzorcev, ni niti zaznavanja. Ob tem pa ne smemo spregledati, da je tudi prirojeno izvirno rezultat evolucije vrste.

Na povezanost spomina in pojma časa je opozoril tudi Weininger (1903), ki ga omenjamo predvsem zaradi tega, ker je bil mnenja, da je emancipacija psihologije od filozofije pravi razlog njenega propada in da naj bi psihologija ostala filozofska, seveda ne po predpostavkah, temveč po svojih skrajnjih namenih. Zavzemal se je za psihologijo kot teoretično biografijo.

Danes vemo, da so možgani sedež duha in mentalnih funkcij. Duha in mentalnih sposobnosti brez vsebine ni, vsebina pa nastaja iz odnosa mentalnih sposobnosti in gmotnih dražljajev iz sveta zunaj nas (fizični svet, kultura) in iz našega telesa. Videti smo ujetniki lastne utelešenosti, ki je ne moremo preseči razen na osnovi posredovanja mentalnih sposobnosti. Stiki s telesom,

\footnotetext{
${ }^{3}$ Nevrologinja Andreja Avberšek mi je v nekem sporočilu po elektronski pošti (22. 6. 2010) o eni izmed prvih verzij tega članka posebej pisala ravno o atraktorjih: „V besedilu velikokrat govorite o atraktorjih (...). Z nevrološkega vidika mi ni všeč, da govorite, da so atraktorji shranjeni v možganih. Bolje bi se mi zdelo, če bi govorili o spominih, ki so v bistvu shranjeni v obliki ojačanih sinaptičnih povezav med določenimi nevroni, in te povezave potem delujejo kot atraktorji, saj jih vzbudi vrsta podobnih inputov«. Sicer pa ima beseda atraktor ali privlačevalec zgodovinski, etimološki in nevrološki vidik. Pojem sestoji iz dveh delov (attractor | \ə-'trak-tər\, privlačevalec, in at-tract | \ə-'trakt \, privlačiti). Prva znana uporaba angl. glagola attract (privlačiti) je zabeležena v 15. stoletju v obliki tranzitivnega glagola (Merriam-Webster Dictionary https://www.merriamwebster.com/). Glagol attract prihaja iz latinske besede attractus, participa glagola attrahere, ad- + trahere (pritegniti). Sinonimi za privlačiti (attract) so pritegniti, privabiti, zapeljati (allure), očarati (koga), premamiti (charm), očarati, pridobiti (captivate), očarati, prevzeti, vzbuditi veliko občudovanje, začarati (fascinate), očarati, začarati (enchant). Privlačiti pomeni sposobnost vplivanja na drugega. Učence privlači šola. Očarati (fascinate) kaže na magičen vpliv in poudarja neučinkovitost poskusov upora. Očarati (enchant) je najmočnejši med temi izrazi, saj poudarja privlačnost agenta in stopnjo užitka, ki ga vzbuja v subjektu, ki je brezupno očaran nad lepoto agenta.
} 
z zunanjim fizičnim svetom in kulturo, vključno s samozavedanjem, so posredovani $\mathrm{z}$ mentalnimi sposobnostmi.

Solipsizem ujetništva utelešenosti (Šercar in Trojar, 2009) reši govor. Po Piagetu predstavlja govor neizogiben, vendar nezadosten pogoj razvoja logičnih operacij (Pijaže, 1988). Neizogiben zato, ker bi brez sistema simboličnega izražanja (govora) operacije ostale v stanju zaporednih akcij, ki se nikoli ne integrirajo v simultane sisteme ali sisteme istočasnih vzajemno odvisnih transformacij. Operacije brez govora bi po drugi strani ostale individualne in ne bi poznale družbene regulacije, ki sledi iz medosebne (angl. interindividual) izmenjave in sodelovanja. Med govorom in mišljenjem obstaja torej genetični krog vzajemnosti pri nastajanju in delovanju. Vendar sta tako govor kot mišljenje odvisna od inteligentnosti, ki obstaja pred pojavom govora in je neodvisna tudi od jezika.

Po Inhelderjevi (1969), sodelavki Jeana Piageta, je objektivno preučevanje miselnih dejavnosti mogoče, ne da bi zapadli v subjektivni mentalizem kot nasprotje behaviorizma. $\mathrm{S}$ časom in razvojem se spreminja struktura mnemonične kode. Ukvarjala se je z odnosom med spominom in splošno strukturo inteligentnosti. Za pojasnitev spomina so potrebne tako figuralne strukture oz. sheme (angl. pattern setting) kot tudi operacije (ki segajo globlje od ravni govora), od katerih je odvisen element razumevanja, ki je skorajda vedno prisoten $v$ spominu. Operacije so relativno neodvisne od govora in omogočajo npr. klasifikacijo z manipuliranjem oz. senzorno-motorno koordinacijo (pri majhnih otrocih), preden postanejo miselne operacije.

Modrost, ki smo jo vzeli za primer, je ena izmed številnih človekovih mentalnih sposobnosti. Nobena človekova mentalna sposobnost brez spomina ni mogoča - vse od zaznavanja naprej, z modrostjo vred. Spomin se je razvijal skozi celotno zgodovino človekovega vzpona, ki se po znanstvenih spoznanjih odvija po teoriji evolucije. Smisel evolucije naj bi bilo čim večje dobro in korist za slehernega posameznika in njegovo vrsto. $Z$ biološkega vidika je ontogeneza kratka rekapitulacija filogeneze. Z vidika historično-kulturne psihologije skupno znanje družbe postaja osebno znanje posameznika.

Modrost je zmogljivost uresničiti vrednote $v$ življenju zase, za druge in za splošno dobro; potemtakem naj bi vključevala predvsem znanje "zakaj" (angl. why) in »kako« (angl. knowhow). Po nevropsihologiji je modrost med drugim zmogljivost prepoznavanja vzorcev (Goldberg, 2007). Prepoznavanje vzorcev je po Herbertu Simonu (1996) najbolj splošno in najbolj učinkovito sredstvo za reševanje problemov. Obliko prepoznavanja vzorcev ima tudi odločanje. Obstoj prepoznavanja vzorcev so že prej zaslutili številni avtorji in šole pod različnimi poimenovanji, predvsem Piaget pod pojmom miselnih operacij oz. vzorcev (shem) (Pijaže, 1988). Vendar modrost ni samo predmet individualne (nevro)psihologije, govorimo lahko tudi o kolektivni modrosti in norosti množic kot o psihosocialnem pojavu (Mackay, 1841).

\section{Poslanstvo (nevro)psihologije}

$\checkmark$ informacijski znanosti je danes zaznati velik interes za filozofijo informacijske znanosti oz. za informacijsko znanost kot uporabno filozofijo. Na čelu tega gibanja je Luciano Floridi (Floridi, 2002; Šercar, 2006). Vendar filozofija, sociologija, politologija in ekonomija niso sposobne pojasniti motivacijskih osnov vedenja posameznikov kot proizvajalcev in uporabnikov informacij. To je poslanstvo psihologije in nevropsihologije oz. kognitivne nevroznanosti. 
Nevropsihologijo zanimajo predvsem anatomske in fiziološke osnove psihičnih pojavov z modrostjo vred.

Moje zanimanje za področje bibliotekarstva, dokumentacije (arhivistike in muzeologije) in informacijske znanosti (informatike) se je začelo leta 1974. Profesor Težak, ki me je navdušil in uvedel $v$ te znanosti in dejavnosti, je poudarjal prav pomen psihičnih vidikov. Moj "sicer pa mislim« je še bolj radikalen kot Težakov in se glasi, da informacijska znanost kot znanost (ne samo po nazivu) brez psihologije oz. brez kognitivne nevroznanosti (Goldberg, 2007) preprosto ni mogoča. Epohalni prispevek ruskega nevropsihologa Aleksandra Romanoviča Lurije je bil predvsem v povezovanju psihologije in znanosti o možganih. $V$ dvajsetih letih 20 . stoletja je Lurija napisal dve knjigi: The Nature of Human Conflicts ( $v$ ruščini, vendar je leta 1932 v ZDA objavil samo angleški prevod) in Speech and Intellect in Child Development, nato pa v tridesetih letih 20. stoletja še Speech and Intellect of Urban, Rural and Homeless Children (samo v ruščini). Lurija je skupaj z Vygotskym prvič predstavil svoj intelektualni manifest $v$ članku The Tool and a Symbol in Child Development (1930). Zaradi vedno večjega dogmatizma in represije oblasti v takratni Sovjetski zvezi se izvirnik ni mogel objaviti doma v ruščini in naposled je bil rokopis izgubljen. $V$ sovjetski znanosti sta bili genetika in kibernetika prepovedani kot buržujski psevdoznanosti, v biologiji in kmetijstvu pa je prevladoval ignorantski neolamarkizem.

Vygotsky je umrl zelo mlad. Za Lurijo pa je bila druga svetovna vojna priložnost, da se popolnoma posveti nevropsihologiji. Med vojno se je Lurija namreč ukvarjal z razvojem nevrorehabilitacijskih metod za številne sovjetske vojake, ranjene v glavo. Leta 1966 je v New Yorku Lurija objavil že omenjeno knjigo Higher Cortical Functions in Man, prvo znanstveno monografijo na področju nevropsihologije, ki je anticipirala nastanek te nove znanstvene discipline $v$ osemdesetih letih 20 . stoletja.

\subsection{Piagetovo pojmovanje modrosti kot racionalnega verovanja: kritika Heideggerjeve fenomenologije}

Zgodovinski razlog, zaradi katerega je filozofija $v$ zahodni civilizaciji veljala za spoznanje, je $v$ tem, da je bila dolgo vzajemno povezana z znanostjo. Za prve grške mislece razlika med znanostjo in filozofijo ni obstajala. Ko so predsokratiki začeli pojmovati na osnovi razuma, in ne več na osnovi simboličnega jezika mitov, so bile vse njihove koncepcije sveta sorodne tako filozofiji kot fiziki (miletska šola) ali matematiki (pitagorejstvo). Vzhodna filozofija je bolj kot zahodna v bistvu modrost.

K znanim splošnim epistemološkim pogojem znanja se od 19. stoletja naprej dodajajo posledice diferenciacije, fragmentarizacije in specializacije znanja, spoznanja in pojava številnih novih znanstvenih disciplin in teorij $z$ informacijsko znanostjo vred.

Danes je resna samo tista skupina epistemologij kot teorij (spo)znanja, ki upoštevajo tudi specializirano epistemologijo ozko specializiranih področij znanja in znanosti. Piaget je ta problem rešil z naslednjo klasifikacijsko shemo klasičnih problemov filozofije:

- metafizika kot iskanje absolutnega;

- etika in estetika kot normativne nespoznavne discipline;

- logika in teorija formalnih norm spoznanja;

- psihologija in sociologija;

- epistemologija ali splošna teorija spoznanja. 
Sleherno spoznanje je podrejeno obstoju epistemičnega subjekta. To je osnova epistemologije. Piaget je sprožil:

- dvom v avtentičnost filozofskega spoznanja in

- zahtevo po popolnem preiskovanju epistemologije filozofskega spoznanja.

Filozofija vsekakor ne prihaja do spoznanja, saj nima sredstev za potrditev ali ovrženje, nima metod, ki spoznanju dejstev podajajo značilnost znanstvenosti. Vendar filozofija lahko vodi k modrosti na osnovi koordinacije vrednot spoznanja z drugimi človekovimi vrednotami na podlagi racionalnega razsojanja. Kajti modrost zahteva angažiranje; mogoče je, da soobstaja več koncepcij modrosti. Potemtakem naj bi bila modrost racionalno verovanje. Toda sodobna filozofija ima veliko smeri iracionalizma in $v$ imenu objektivnosti naj bi bila tako definicija filozofije kot modrosti zmožna obsegati tudi filozofijo iracionalizma. Heidegger pravi, da se mišljenje začne šele tedaj, ko spoznamo, da je (zdravi) razum najhujši sovražnik mišljenja in v tem primeru gre za vrsto neracionalne modrosti.

Razlika med modrostjo kot racionalnim verovanjem in sistemom spoznanja je $v$ tem, da modrost spoznanju dodaja:

- angažma ali dejavnik odločanja, ki je edini sposoben npr. podati smisel življenja;

- domneve (hipoteze), ki postajajo spoznanje po potrditvi z dokazi.

Če hočemo živeti v skladu s sprejetim smislom življenja, smo prisiljeni te domneve upoštevati kot verovanje. Če npr. verjamemo v človekovo svobodo, je to stvar modrosti, ne pa spoznanja, saj zadeva ni znanstveno potrjena. Radikalna razmejitev med modrostjo in spoznanjem ni možna, saj spoznavnih sistemov brez predpostavk in domnev ni. Če je verovanje mogoče brez znanja, znanje ni mogoče brez verovanja. Weininger (1903) na to temo pravi takole (parafraziram): Verovanje brez znanja je ne samo mogoče, temveč so tudi čudeži, ki naj bi potrjevali resničnost nekega verovanja, posledica, in ne kronski dokazi le-tega. Za razliko pa znanosti brez "verovanj", tj. brez predznanstvenih predpostavk mišljenja, sploh niso mogoče. Heidegger $(1997,1927)$ je o predpostavkah zapisal: „Filozofija si nikoli ne bo želela preklicati svojih 'predpostavk', ne sme pa jih tudi zgolj priznavati. Predpostavke pojmuje in z njimi obenem koreniteje razvije to, za kar te predpostavke so predpostavke."

Po Kantu področje praktičnega uma vključuje tisto, kar človek mora delati (kategorični imperativ) in čemur se lahko nadeja. Smisel svobode je $v$ tem, da je pogoj moralne odgovornosti. Lahko smo odgovorni samo, če o svojih dejanjih in mislih odločamo svobodno in smo ob tem tudi duševno prištevni. Vzemimo tudi primer smisla ideje, da so vsi ljudje enaki. Prvič, ideja izhaja iz težnje, ki ni prirojena. Psiholog lahko raziskuje stališča ljudi do te ideje, ki je lahko sestavni del modrosti kot predmeta psihologije. Spoznanje je druga vrsta smisla - je epistemični smisel. Vedno gre za dva smisla: eden je spoznavni (objektivna resnica) in drugi življenjski. Nekateri misleci ju poskusijo združiti v enoten koncept pomena.

Epistemološki pogoji epistemologije smisla so mogoči samo kot predpostavke in izkaže se, da mišljenje brez predpostavk sploh ni možno. Toda pogosto so tudi hipoteze deduktivno izpeljane iz že preverjenih dejstev. Dober znanstvenik kontrolira tudi hipoteze. Z razvojem znanja glede na dejstva se zmanjšuje tudi potreba po hipotezah. 
Epistemologija je celo najboljši sodobni primer discipline, katere namen je smisel in ki je predpogoj znanja, iz filozofske discipline pa se vedno bolj spreminja $v$ področje interdisciplinarnega znanstvenega raziskovanja, ki vključuje tudi informacijsko znanost kot vrsto uporabne epistemologije. Napoved Piageta, da se bo ponovno vzpostavila povezanost filozofije in znanosti, potem ko se zmanjša vpliv fenomenološke in eksistencialistične filozofije, predvsem pa Heideggerja (!), se je počasi uresničila.

Piaget je bil tudi prepričan, da razvoj interdisciplinarnih raziskav slabša predsodek o vodilni in sintetični vlogi filozofije. O povezanosti mišljenja in možganov in o tem, da se filozofi v svoji osamitvi zelo motijo glede odnosa duha in možganov (telesa), je pisal, kot rečeno, že Galen.

Modrost brez resnice, ki predstavlja objektivno kognitivno dimenzijo, ni mogoča. Modrost je po Piagetu, kot rečeno, racionalno verovanje, Heideggerjeva filozofija pa je primer neracionalnega verovanja. Modrost kot koordinacija vrednot oz. verovanje predpostavlja razum in mišljenje. Toda razum premaga znanje, saj lahko posreduje tudi pri odločanju. Glavni problem je smisel smisla. Obstaja epistemični in praktični smisel. Afirmacija svobode ima vsekakor epistemični smisel. To je predpostavka, po kateri stanja $\mathrm{t}+1$ ne moremo deducirati brez stanja t. Tukaj je prisoten skupek fizičnih, psiholoških in logično matematičnih pomenov. Kar se tiče praktičnega smisla, svoboda vsekakor vsebuje smisel, ki vključuje našo odgovornost. Za njihovo povezovanje potrebujemo modrost, vendar nam ta ne omogoča priti do spoznanja in resnice.

Verovanje spada v širši pojem mišljenja. Psihologi klasificirajo verovanje kot tovrstno potrebo, potrebo po verovanju. Maslow (1943) razvršča potrebo po verovanju $v$ isto kategorijo motivacij po varnosti (kot eno izmed vrst determinant vedenja) s potrebo po znanju (znanost) in modrosti (filozofija) vred. Potemtakem je verovanje nekaj elementarnega, nekaj, kar ni izvedeno, enako kot mišljenje samo. Mišljenje in verovanje sta neločljivo dialektično povezana. Očitno je, da mišljenja brez predpostavk, tj. brez verovanja, ni. Tako mišljenje vključuje verovanje kot svojo predpostavko in predpogoj, ki ga tudi zunaj samega mišljenja ni.

Znan je naslednji Piagetov trojček: refleksija - dedukcija - eksperiment. Refleksija naj bi imela hevristično funkcijo, dedukcija in eksperiment pa spoznavno funkcijo potrditve, ki je bistvenega pomena za resnico. Refleksija je očitno predhodnik tako eksperimenta kot dedukcije in jima nato tudi sledi. Refleksija je nujna na vseh nivojih. Intuicija, za katero je Husserl rekel, da je kot neločljiv proizvod subjekta in objekta povezana s fenomeni, se zelo razlikuje od refleksije. Refleksija je, kot rečeno, nepogrešljiva na vseh ravneh, medtem ko se potreba po intuiciji zmanjšuje z napredovanjem spoznanja.

Husserlova fenomenologija je primer filozofske psihologije - podobna primera sta Sartrova teorija čustev in Bergsonova teorija spomina, na katero se sicer nevropsihologija ni nikoli ozirala. Ali je psihologiji kot eksperimentalni znanosti sploh mesto na filozofski fakulteti, je že dlje časa odprto vprašanje. Psihologija razvija svojo epistemologijo in ne potrebuje filozofov kot posrednikov. To velja tudi za druge znanosti ( $z$ informacijsko znanostjo vred), ki zagotavljajo razvoj lastnega epistemološkega smisla in svojo lastno refleksijo.

Verovanje ima lastnost, da se tistim, ki ga ne delijo, ne zdi kot spoznanje. Povezovanje sposobnosti in verovanja pelje $k$ hierarhičnemu sistemu piramide, na vrhu katere so maloštevilni pooblaščenci. Filozofsko spoznanje po Piagetu ni mogoče. Mogoče je le znanstveno spoznanje. Naše osnove so v biologiji, povezanost biološkega in mentalnega je 
znanstveno dejstvo. Vendar je znanstvena dejavnost kot praksa vključena $v$ širši svet moralnega ravnanja, smisla življenja in zadnjih namenov.

Za pojasnjevanje jezika je pooblaščena predvsem eksperimentalna psihologija. Zgodovina žive filozofije je zgodovina problemov, ki jih zastavlja refleksija, $z$ anticipacijami in s filozofsko refleksijo, vendar jih ta ne rešuje, ampak jih rešujejo specializirane znanosti, ki so nastale iz filozofije z diferenciacijo. Kuzanski je intuitivno zaslutil kontinuiteto $v$ naravi, vendar pa jo je dokazal Leibniz - Leibniz kot matematik, in ne kot filozof - z infinitezimalnim računom in izračunom te kontinuitete. Tako kontinuiteto ima tudi refleksija, brez katere bi bili znanstveni problemi zagotovo bolj omejeni.

Obstajajo problemi, ki jih znanost ne uspeva rešiti in podaja le začasno rešitev. Problemi lahko imajo praktično življenjsko pomembnost in epistemični »smisel«. Zabloda filozofije je, da ima te epistemične začasne rešitve za oblike spoznanja. Vendar če jih tolmačimo kot modrost (ali modrosti $v$ množini, saj so začasne rešitve problemov mnogoštevilne), tj. kot racionalno verovanje, smo se tej napaki izognili.

\subsection{Od asociacionizma do miselnih operacij}

Po Piagetu in Inhelderjevi asociacionizem zreducira intelektualne operacije na preprosto igro asociacij (Pijaže in Inhelder, 1988). Reakcijo na ta asociacijski redukcionizem predstavlja würzburška šola, vendar je bila posledica vrnitev k logicizmu filozofov, ki opisujejo mišljenje na osnovi klasične formalne logike. Testi, ki so jih predložili kot program merjenja intelektualnih operacij, vsebujejo samo silogizme - izpraševanec naj bi prišel do zaključka na podlagi premis. Tako filozofski introspekciji kot tudi behaviorizmu izmikajo operacije, ki so pri odraslem človeku povezane $v$ zapletene strukture; le-te nastajajo med razvojem od rojstva do odrasle dobe, ta razvoj pa terja uporabo genetične metode razvojne psihologije.

Operacije predstavljajo avtentično psihološko realnost in niso izraz, izposojen iz logike. Intelektualne operacije imajo učinek, ki je merljiv. Obstoj operacij na področju psihologije mišljenja so zaslutili številni avtorji pod različnimi poimenovanji. Binet (1903) je poudarjal specifično obeležje afirmacij in negacij, relacijskih izrazov itd., ki so po Piagetu operacije, za razliko od asociacij slik. Spearman (1923) je delno odkril operacijsko naravo inteligentnega dejanja. Inteligentnost se razvija $v$ treh etapah: razumevanje izkušenj, edukcija relacij in edukcija korelatov. Kot empirik si ni zastavljal vprašanja o strukturiranosti izkušenj, temveč samo o njihovem razumevanju. Relacije se tudi ne oblikujejo, temveč izpeljujejo (eduktirajo) iz izkušenj, ki jih (relacije) vnaprej vsebujejo. Korelati so relacije med relacijami in so tudi eduktirani iz izkušenj oz. stvarnosti. Čeprav je kot empirist nekako podcenjeval vlogo samoaktivnosti subjekta, ima edukcija kot vrsta multiplikativne koordinacije relacij, ki ustreza matriki ali tablici z dvema vhodoma, pravzaprav obliko Piagetove operacije.

Geštaltisti so v eksperimentalni psihologiji prvi odkrili logične strukture, ki niso vnaprej postulirane. Pri zaznavanju so izhajali iz hipoteze polja, zavračajoč asociacijski atomizem. Celota se razlikuje od preprostega seštevka delov. Gre za neaditivno kompozicijo (Wertheimer, 1945). Enostavnejšo rešitev so podali predstavniki psihologije mišljenja (nem. Denkpsychologie). Glavni predstavnik te tradicije Otto Selz (1913, 1922, 1924; Hark, 2004) mišljenje razume kot ogledalo logike. $\mathrm{V}$ primeru denkpsihologov gre za vrsto logičnopsihološkega paralelizma. Vendar izomorfizma med logiko subjekta, s katero se ukvarja psiholog, in logiko logika, ki presega logiko subjekta, ni. Funkcija mišljenja naj bi bila, da izraža 
formalno logiko, ki obstaja a priori. Verjetneje pa je, da je logika rezultat aksiomatizacije mišljenja. Denkpsihologi so se omejili na analizo mišljenja odraslih oseb in paralelizem med logičnimi strukturami in miselnimi dejanji je posledica tega.

Claparède (1933) je izumil ingeniozno metodo za analizo dejanj inteligentnosti, metodo glasnega razmišljanja, ki se mora izvajati pri reševanju problemov. Vendar je Claparède ugotovil, da metoda poskusov in napak, s katero rešujemo probleme in ki je izhodiščno stališče, nikoli ni čisto naključno, saj z reševanjem problemov že od samega začetka deloma upravljajo nekatere povezave, ki niso asociacije, temveč povezave, ki se pojavljajo z neko vrsto notranje nujnosti. Claparède jih je poimenoval implikacije, v bistvu pa gre za hipoteze.

Po Brunerju, Goodnowu in Austinu (1956) zaporedni kazalci subjekta pri reševanju problemov sestojijo ne iz asociacij, ki jih preprosto določajo prejšnje izkušnje, temveč iz odločitev, ki intervenirajo v obliki spoprijemanja subjekta z objekti ali dogodki. Te odločitve ali strategije, ki se uporabljajo v teorijah iger, so zelo sorodne Piagetovemu pojmu operacija.

Berlyne (1960) je uvedel pojem odgovorov-transformacij, ki ustrezajo pojmu operacija poleg odgovorov-kopij, ki se nanašajo na stanja. Odgovori-transformacije preoblikujejo odgovorekopije. $V$ psihološke raziskave je uvedel tudi teorijo informacij. Zaznavna radovednost je gon (angl. drive), ki ga zaznava zmanjšuje. Epistemološka radovednost pa je gon, ki ga zmanjšuje pridobivanje znanja. Glavna neodvisna spremenljivka, ki vpliva na zaznavno radovednost, je predvsem zapletenost okoliščin glede dražljajev in je povezana z relativno entropijo (razmerje med sprejetimi informacijami iz določene slike in največjim številom informacij, ki jih lahko prejmemo iz slike $z$ isto količino informacij), ki je obratna od redundance in predstavlja pomembno lastnost vidnih slik. Ena izmed glavnih determinant epistemološke radovednosti pa je v stopnji spoznane razlike med simboličnimi odgovori, ki so jih vzbudili prisotni dražljaji. Ta neodvisna spremenljivka $v$ matematični ali statistični teoriji informacij Shannona in Weaverja (1949) je znana kot entropija oz. nedoločenost. Epistemološka radovednost narašča s številom prejšnjih zadovoljitev gona v podobnih situacijah. Po Berlynu na radovednost poleg relativne in absolutne entropije ter spoznane razlike vpliva tudi nepričakovanost.

Naloga evolucijske psihologije je odkriti, kako se strukture oblikujejo, ne pa, kaj predstavljajo, ko se enkrat stabilizirajo. Dokončno stanje lahko razumemo samo, če smo spoznali razvojni proces oblikovanja. Logično-matematične aktivnosti je treba razumeti psihološko kot produktivno podaljševanje senzorno-motorne koordinacije, ki ima kot operacija psihološko avtentičnost in je prvo osnovno obeležje operacije. Drugo osnovno obeležje operacije je, da so operacije vedno strukturirane v celotne sisteme. Glavne strukture, opisane v splošni algebri (skupine in mreže ter njihovi derivati), se oblikujejo, začenši od ravni konkretnih operacij, ki so most med koordinacijo akcij in formalizacijo mišljenja do prehoda s konkretnih na abstraktne strukture na osnovi načinov transformacije. Manifestacije teh transformacij in njihovo vlogo v mišljenju odraslih logiki niso zasledili, odkrili pa so jih razvojni psihologi na čelu s Piagetom.

\subsection{Mesto modrosti v teoriji psihosocialnega razvoja}

Po Eriksonu (1968) je modrost zadnji stadij (od 65. leta starosti do smrti) izmed osmih stadijev njegove teorije psihosocialnega razvoja. Naloga slehernega posameznika je rešiti psihološki konflikt med integriteto in obupom, pridobivanje modrosti pa je ugoden izhod iz tega prepada. Vsak človek ni sposoben razviti modrosti. Proti koncu življenja se kot psihološka bitja soočamo z novo krizo identitete, ki jo lahko izrazimo z besedami: „Jaz sem tisto, kar me bo preživelo! « 


\section{Anatomske, fiziološke in psihične osnove individualne modrosti (posameznikov)}

\subsection{Možganski mehanizmi modrosti}

Modrost je treba preučiti kot psihološki in socialni fenomen, preden se lahko poglobimo $v$ možganske mehanizme kognitivnih dobičkov s staranjem. To sva z Valerijo Trojar opravila v prvem delu članka pod naslovom Modrost kot predmet informacijske znanosti (Šercar in Trojar, 2009). Kljub neprekinjenemu zanimanju za modrost, ki se je začelo pred pet tisoč leti in traja vse do danes - kot piše Elkhonon Goldberg (2007) -, ni bilo resnega poskusa, da se pojasnijo možganski mehanizmi modrosti. Goldberg je nastavil hierarhijo modrosti po vrstah, ki kažejo izkušnje glede na potreben čas za njihov razvoj:

- milijone let za razvoj modrosti rodu oz. razreda, ki se izraža v osnovnih čustvenih odgovorih na dražljaje in zaznavno diskriminacijo;

- tisoče let za razvoj modrosti vrste, ki se izraža v jeziku in drugih simboličnih sistemih;

- leta našega življenja za razvoj modrosti skupine, ki se izraža v znanju in sposobnostih, nad katerimi ima npr. poklicna skupina monopol in ji omogočajo izvajanje zapletenih nalog;

- modrost posameznika, ki je glavni predmet Goldbergove knjige o paradoksu modrosti z naslovom The wisdom paradox: how your mind can grow stronger as your brain grows older in se izraža $v$ inteligentnosti, kulturnih sredstvih prepoznavanja vzorcev, med katerimi je jezik najpomembnejše orodje.

Po Goldbergu je modrost biološka in teoretično-evolucijska kategorija. Duhovne/mentalne sposobnosti so funkcije možganov in tudi modrost kot intelektualna sposobnost je funkcija možganov. Proizvod možganov je tudi osebnost.

Staranje prinaša tako izgube kot tudi dobitke. Staranje duha/možganov ima svoje uspehe, ki jih lahko prinese samo starost. S staranjem lahko izgubimo moč spomina in trajnostno koncentracijo. Vendar s staranjem lahko pridobimo modrost ali vsaj izkušnje in kompetence. Med izgubami in dobitki obstaja ravnovesje.

Najmočnejši mehanizem uspešnega mišljenja je prepoznavanje vzorcev. Odločanje ima še bolj kot reševanje problemov obliko prepoznavanja vzorcev. Prehod z reševanja problemov na prepoznavanje vzorcev spreminja način, kako različni deli možganov prispevajo k tovrstnemu procesu. Mišljenje je funkcija neokorteksa. Razmerje med uporabo leve in desne hemisfere se spreminja in pri tem najverjetneje upada odvisnost od desne hemisfere in narašča odvisnost od leve hemisfere možganov.

Modrost ali vsaj določen bistven del modrosti posedujejo tisti, ki so bili sposobni oblikovati veliko število vzorcev mišljenja, vsak od teh vzorcev pa vključuje številne pripadajoče izkušnje. Kritiki so Goldberga napadli zaradi »škandaloznega" poenostavljanja. V starosti smo deležni dividend, ki jih prinaša modrost. Te dividende starosti omogočajo odločanje sorazmerno brez težav, kar terja zelo skromne nevronske vire, in sicer tako dolgo, dokler so vzorci ohranjeni kot nevronske entitete. Merodajnost in izkušnje kot rojaki modrosti so lahko odporne proti eroziji nevronov. Evolucijsko najmlajši in najzapletenejši del možganov se pri posamezniku tudi razvija najkasneje (ob 18 . in celo 30 . letu starosti). Prefrontalni korteks je zelo ranljiv pri vrsti 
nevroloških in psihiatričnih bolezni, kot so demenca, shizofrenija in travmatske možganske poškodbe (prim. slika 1).

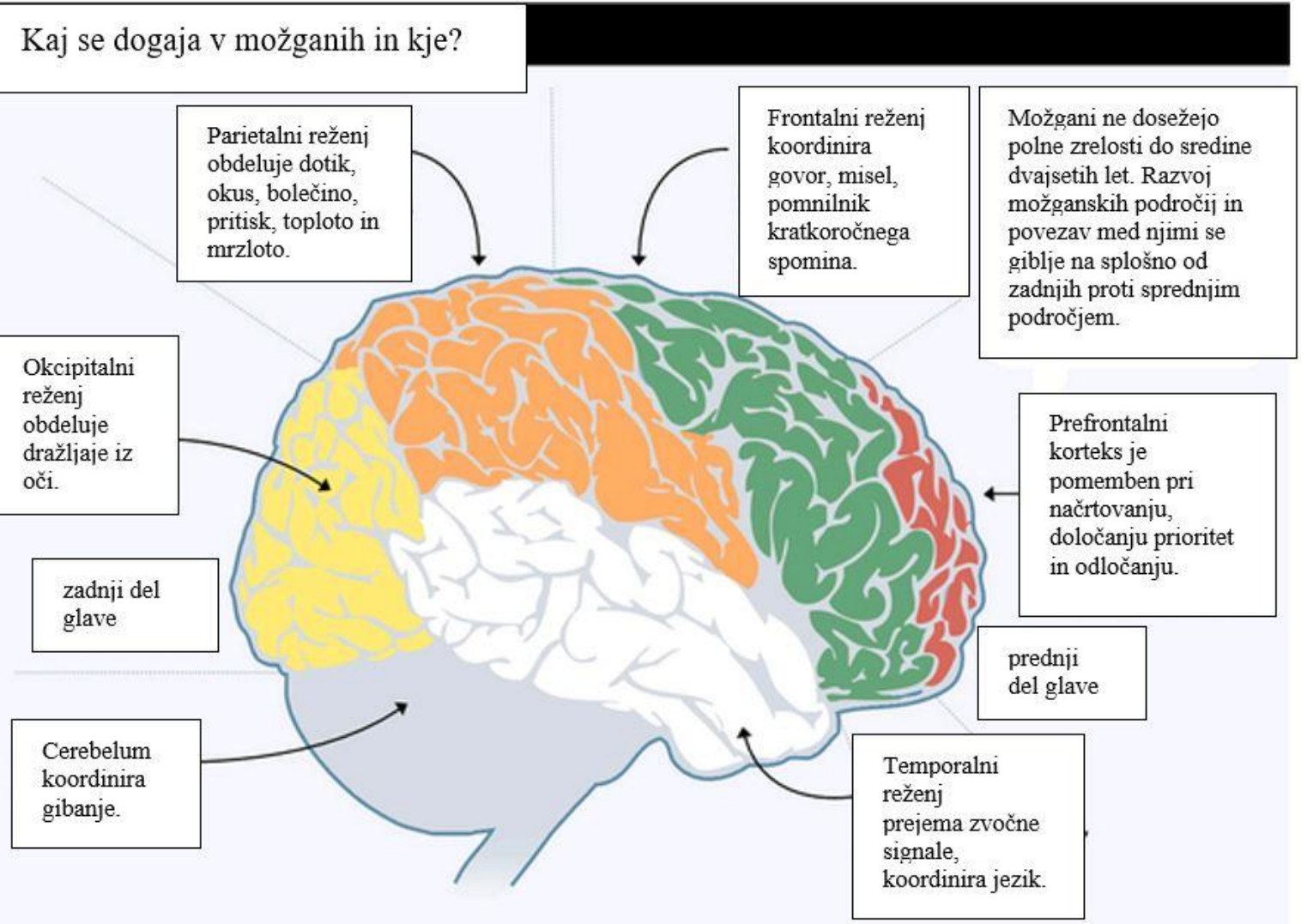

Slika 1: Kaj se dogaja v možganih in kje (prirejeno po MIT, https://www.virtuallibrary.info/learningyour-brain-and-neuroscience.html)

Goldberg loči tri dobe možganov: razvoj, zrelost in starost. Razvoj traja do 3. desetletja življenja. Razvoj možganov je z več plati zapleten proces, ki se začne z rojstvom nevronov. Nevroni so možganske celice, ki so najneposredneje vključene $v$ obdelavo informacij in $s$ selitvijo informacij z namenom najti jim ustrezno mesto v kompleksni organizaciji možganov.

Naš optimizem glede možnosti spoznavanja možganov temelji ravno na njihovi zapletenosti. Slovenska nevroznanstvenica Maja Bresjanac (Zgonik, 2013) je mnenja, da manjka na področju raziskovanja možganov predvsem sinteza, ki bi povezala izjemno količino doslej pridobljenega znanja o delovanju možganov. Drugače pa ne vidi meja spoznavanja možganov, ki bi bile nepremagljive. Pri tem navaja paradoks znanega južnoafriškega biologa Lyalla Watsona. Če bi bili namreč naši možgani tako preprosti, da bi jih lahko razumeli, bi bili mi sami tako preprosti, da nam to ne bi uspelo (cit. po Chang, 2006, str. 539).

Po nevrološkem pravilu razvoja in propada angleškega nevrologa Johna Hughlingsa Jacksona (1884), ustanovitelja znane revije Brain, možganske strukture neokorteksa, ki so filogenetsko (razvojno) mlajše, z normalnim staranjem propadajo hitreje kot druge možganske strukture. Hipokampus, ki je pomemben za oblikovanje novih spominov, z normalnim staranjem propada zelo počasi. Mehanizem zmanjšanja (angl. dampening) oblikovanja presežka novih informacij najbrž upočasnjuje staranje človekovih možganov. Ljudje smo bolj kot druge vrste primatov odvisni od pridobljenih kognitivnih vzorcev, s katerimi nekako tekmujejo nove informacije. Pri 
Alzheimerjevi bolezni pa nevroni hipokampusa in nekaterih drugih starejših struktur možganov propadajo hitreje kot nevroni frontalnega režnja. Ta vzorec prizadetosti pomaga pri diagnosticiranju te bolezni (Paradise, Cooper in Livingston, 2009).

Spremembe anatomije možganov se pretvarjajo $v$ spremembe funkcij možganov, te pa $v$ kognitivne spremembe. Vprašanje je, kako, vendar pa hitrost mentalnih operacij s staranjem zagotovo upada. To se posebej nanaša na funkcije frontalnega režnja, ki vključujejo:

- delovni spomin (sposobnost zadrževanja določenih informacij med kognitivno obdelavo, za katero so te informacije bistvene);

- mentalno fleksibilnost (sposobnost hitrega preklopa z enega mentalnega procesa na drugega in od enega vzorca na drugega);

- selektivno pozornost (sposobnost izbiranja najbolj pomembnih dogodkov $v$ okolju in koncentracije na njih);

- deljeno pozornost (sposobnost premikanja pozornosti nazaj in naprej med aktivnostmi, ki se izvajajo vzporedno);

- abstraktno mišljenje;

- načrtovanje oz. oblikovanje strategij.

Wynn in Coolidge (2011; Bouton, 2011) sta podala paleoantropološke in nevropsihološke dokaze, povezane z delovnim spominom, ki pojasnjujejo izumrtje neandertalcev in preživetje homo sapiensa. Vzrok izumrtja neandertalcev je ena od največjih antropoloških skrivnostih. Wynn in Coolidge domnevata, da se je pred približno 100.000 leti zgodila genska mutacija, ki je »premrežila« frontalni lobus naših prednikov, s čimer se je povečal delovni pomnilnik, čeprav so imeli neandertalci za približno $9 \%$ večje možgane. Delovni spomin pa omogoča obdelavo informacij za prilagajanje na nove situacije, brez česar ni mogoče preživeti.

Erozija sposobnosti učenja novih informacij spada med najzgodnejše pokazatelje kognitivnega staranja. Vse te kognitivne spremembe so dokumentirane $z$ laboratorijskimi nevropsihološkimi testi. Vendar pa pri starih ljudeh kljub kognitivnemu upadanju s staranjem obstaja misteriozna sposobnost kognitivne ekspertize. Njeni mehanizmi so bili dolgo nepojasnjeni. Proučevanje teh mehanizmov je glavna tema Goldbergovega proučevanja (2007). Kognitivna ekspertiza, ki ima skrivnostno sposobnost upiranja nedobrodošlim posledicam staranja, je $v$ sozvočju z visoko vrednotenima lastnostma, povezanima $z$ dobo zrelosti: kompetentnostjo in modrostjo. Gre za paradoks možganov, ki se ne starajo.

Kognitivna ekspertiza, kompetentnost in modrost so tudi proizvodi možganov, in ta paradoks je vprašanje, s katerim sta se morali spoprijeti nevropsihologija in nevroznanost, saj so $v$ ozadju tudi odgovarjajoči nevronski mehanizmi. Goldberg se sprašuje, kaj v evoluciji pomeni življenje posameznikov do globoke starosti, ki nič več biološko ne prispevajo k nadaljevanju vrste. Ena izmed možnosti je, da starostniki bistveno prispevajo $k$ preživetju vrste $z$ drugimi sredstvi - posebej skozi akumulacijo in prenos znanja na nove generacije prek sredstev kulture, kot je jezik. Zadeva, ki je očitna za znanstvenike, je $v$ glavnem spregledana $v$ poljudni kulturi.

Prvič, nekateri ljudje celo dosežejo mentalno vitalnost v pozni dobi. Drugič, delna izguba mentalne moči ne napoveduje mejnega »kognitivnega bedaka«, saj oseba lahko ostane produktivna in kognitivno sposobna na področjih politike, umetnosti, filozofije in znanosti ne 
glede na merljiv kognitivni upad in celo na zgodnjo demenco in Alzheimerjevo bolezen. Primeri takšne kognitivne sposobnosti, ne glede na nesporen kognitivni upad, so v politiki, primera neverjetne artistične vitalnosti ob Alzheimerjevi bolezni pa sta baskijski kipar Eduardo Chillida in ameriški slikar Willem de Kooning.

Učinke nevrološke erozije pri teh osebah kompenzira bogata knjižnica mehanizmov za prepoznavanje vzorcev, ki so bili oblikovani v njihovih možganih v zgodnejših desetletjih. Kot rečeno, ni sporno, da kognitivni vzorci kljub mentalni eroziji spomina in pozornosti omogočajo, da se spoprimemo z vrsto zapletenih situacij znotraj področja, ki ga strokovno obvladujemo. Vprašanje pa je, kako se ti vzorci oblikujejo in kaj jih ščiti pred erozivnimi učinki mentalnega upada.

Demence so skupina nevrodegenerativnih bolezni, za katere je značilen sekundaren upad kognitivnih funkcij, ki je dovolj velik, da vpliva na vsakodnevne aktivnosti. Incidenca demence $\mathrm{s}$ starostjo narašča. $\mathrm{V}$ zadnjih desetih let se je paradigma $\vee$ nevroznanosti premaknila pod vplivom dokazov, da aktivno mentalno življenje preoblikuje možgane in jih ščiti pred biološkim razdejanjem. Višja izobrazba in mentalna aktivnost pomenita višjo kognitivno rezervo. Tako se pri ljudeh z višjo izobrazbo kognitivni upad pojavi kasneje, čeprav so že prisotne patološke spremembe $v$ možganih $v$ okviru Alzheimerjeve bolezni.

Kompetentnost je posebna sposobnost prepoznavanja podobnosti med dozdevno novimi problemi in problemi, ki smo jih rešili prej. Prepoznavanje vzorcev je sposobnost prepoznavanja novega objekta ali novega problema kot člana že znanega razreda objektov in problemov. Kompetentni ljudje imajo veliko zbirko takih mentalnih vzorcev. Psihologi so zasledili kontinuum med kompetentnostjo in modrostjo kot najvišjim pokazateljem kompetentnosti. Vendar modrost ni samo globok vpogled $v$ naravo stvari, temveč tudi predirno razumevanje dejanja, ki je potrebno za njihovo spreminjanje.

Genialnost in talent sta praviloma povezana z mladostjo. Modrost in kompetentnost sta rezultat staranja. Goldberg se je zavestno omejil na reševanje problemov, ki je eden izmed vidikov modrosti, $s$ katerim se večinoma ukvarja nevroznanost, ali z drugimi besedami povedano, s kognitivno dimenzijo modrosti. Najmočnejši in najbrž glavni mehanizem uspešnega reševanja problemov je prepoznavanje vzorcev (Simon, 1996). Glavni vprašanji Goldberga (2007) se glasita:

- Kaj sta modrost in kompetentnost za razliko od drugih pokazateljev duha, npr. spomina in pozornosti, ki s staranjem upadata?

- Kaj je to, kar modrosti in kompetentnosti omogoča, da preživita razdejanje, ki ga povzroča staranje?

Procesi prepoznavanja vzorcev so mešanica dejavnikov dednosti in okolja. Prispevek narave (angl. nature) in izkušenj (angl. nurture) variira od ene vrste prepoznavanja vzorcev do druge in vključuje zelo različna časovna obdobja - od milijonov let do samo nekaj let. Obstaja več vrst modrosti. Vrste, ki so imele modrost rodu v možganih v obliki, razmeroma pripravljeni za uporabo, so imele tudi večjo možnost za preživetje (strah pred kačami, izogibanje ognju, občutek radosti pri vzhodu Sonca ...). Filogenetski spomin so nevroni v vizualnem korteksu, uglašeni za odgovor na določene enostavne dražljaje iz okolja, ki je diskriminacijski za posamezno vrsto in pomemben za njeno preživetje. Različne vrste imajo različne repertoarje 
skupnega spomina. Ljudje smo modra vrsta in lahko govorimo o modrosti kulture, ki vključuje prepoznavanje vzorcev, kristaliziranih v kulturi.

Veliko tega, kar vključuje kultura, je način a) shranjevanja in prenosa kolektivne modrosti z generacije na generacijo in b) uporabe kolektivne modrosti s strani slehernega posameznika. Prenos tega znanja temelji na vrsti simboličnih sistemov, predvsem na jeziku (ki nota bene nima vgrajenih filtrov resnice za razlikovanje od neresnice in proizvodov domišljije, razen jezikovnih pravil). Vendar je jezik veliko več kot le sredstvo za beleženje znanja, saj prav tako postavlja vzorce, ki oblikujejo naše mišljenje in spoznanje. Zbirka teh vzorcev predstavlja kolektivno modrost družbe za odkritje novih vzorcev s prihrankom. Sestavni del sistema vzorcev je tudi poznavanje pomena besed. Jezik ni samo sredstvo komuniciranja, saj omogoča taksonomijo kot način kategorizacije stvarnega neskončnega števila stvari, dogodkov in vtisov (gramatična struktura jezika), razumevanje odnosov med stvarmi (leksična in pojmovna struktura jezika) itd.

Modrost ni samo opisna, je prav tako predpisna. Lingvisti so se dolgo ukvarjali s predikatno naravo jezika. $V$ osredju strukture jezika je predstava dejanj, povezana z različnimi stvarmi in atributi. Jezik kot sistem prepoznavanja vzorcev nam omogoča narediti več od klasificiranja stvari - omogoča, da odločamo, kako delovati, upoštevaje objektivno stvarnost. Jezik je tudi pragmatično sredstvo. Podobno kot njegov nevronski medij (korteks) je jezik zelo fleksibilen sistem s trajno zmogljivostjo prilagajanja spremembam. Leksične vsebine različnih jezikov so zelo podobne, saj smo obkroženi s podobnimi stvarmi in vključeni v podobna dejanja. Tudi gramatike različnih jezikov so podobne, saj kažejo podobne oblike odnosov med stvarmi.

Vendar pa jeziki odražajo tudi specifičnosti življenja in okolja. Po Simonu (1996) na posebnosti oblikovanja jezika vpliva bolj okolje kot nevronske organizacije. Zapletenost ravnanja organizmov je v veliki meri odraz okolja, in ne samo notranje strukture organizma. Zapletena steza mravelj na zapletenem terenu je bolj posledica konfiguracije terena kot nevronskih in lokomotornih sistemov pri mravljah. Majhna bitja popolnoma različne vrste (npr. polž ali gosenica) bodo šla po isti poti, kljub dejstvu, da se njihova interna organizacija zelo razlikuje od organizacije mravlj. Majhen robot v istem okolju bo »navigiral« po podobni poti. Podobno se oblikujejo tudi naši jeziki.

\subsection{Spomini, prepoznavanje vzorcev in modrost}

Moč modrosti po navadi naredi vtis na presenečenega opazovalca kot takojšnje spoznanje, dozdevno brez prizadevanja, rešitve za domnevno težaven, nepredviden problem. Modrost je tudi sposobnost predvidevanja dogodkov, ki doletijo ljudi popolnoma nepripravljene. Kot rečeno se pojav modrosti z vso svojo zapletenostjo ne sme zreducirati izključno na zmogljivost za prepoznavanje vzorcev na visoki ravni. Toda taka zmogljivost prepoznavanja vzorcev vključuje zelo pomemben element modrosti, ki pomeni, da ima oseba, ki poseduje modrost, sposobnost prepoznavanja velikega števila vzorcev, vsak od teh pa obsega razred pomembnih situacij v celoti. Ta sposobnost je rezultat velikega števila spominov, ki so shranjeni v možganih in delujejo kot atraktorji (angl. attractor).

Za nabiranje in oblikovanje atraktorjev za prepoznavanje vzorcev je potreben določen čas. Vzorci, ki nam omogočajo najti hitre rešitve za vrsto problemov, so splošni spomini, ki se $s$ staranjem kopičijo. Tudi spretnost za intuitivno odločanje se kopiči s staranjem. Intuicijo si pogosto predstavljamo kot antitezo analitičnemu odločanju, kot nekaj, kar je neanalitično oz. 
predanalitično. Vendar pa predstavlja intuicija dejansko zgostitev izkušenj, ki so bile prej analitične. Intuicija je stisnjena in kristalizirana analiza. Intuitivno odločanje je potemtakem postanalitično, in ne predanalitično oz. neanalitično; predstavlja rezultat analitičnih procesov, ki so do te mere zgoščeni, da njihove notranje strukture ne doume niti oseba, ki jih uporablja. Postanalitično naravo intuitivnega odločanja je poudarjal Simon (1996). Gre za, kot rečeno, filogenetsko modrost. Ta modrost je anatomsko lokalizirana $v$ amigdali, majhni zbirki nevronov znotraj temporalnega režnja. $V$ amigdali je modrost vrste, ki se je razvijala milijone let, $v$ neokorteksu in njegovih povezavah z drugimi deli možganov pa je shranjena modrost (oz. kompetentnost) posameznika, ki se je razvila $v$ njegovem življenju. Utelešena je $v$ trdnih nevroloških povezavah. Te povezave pridobijo, kot je že orisano, oblike atraktorjev.

Snyder et al. (2003) so z metodo TMS (angl. Transcranial Magnetic Stimulation) dokazali, da je cena teh hitrih mehanizmov prepoznavanja vzorcev višja, kot si mislimo, saj taki vzorci lahko tu in tam zgrešijo cilj in so potemtakem naše reakcije, ki so odvisne od teh mehanizmov, neustrezne (npr. atavistični strah pred majhnimi krokodili, ki so popolnoma nenevarni). Drugače pa so kognitivni vzorci zelo prilagodljivi.

Intuitivno odločanje je razkošje mentalne ekonomije, ki temelji na velikanski količini prejšnjih izkušenj oz. znanja. Primer te ekonomije je naša sposobnost branja časnika brez čitanja $v$ strogem smislu besede. Na podlagi prepoznavanja naslova članka nam včasih sploh ni treba brati članka, saj poznamo njegovo vsebino. Vse informacije bi bili seveda sposobni izvleči tudi brez predznanja, vendar bi v tem primeru potrebovali najmanj 30 minut ali celo eno uro branja članka $v$ celoti, da pridemo do teh informacij. Ta proces terja veliko pozornosti, spomina in jezikovnih sposobnosti. Zahvaljujoč predznanju pa potrebujemo le 30 sekund. Tukaj je mentalna ekonomija nam $v$ prid. Načelo predhodno nakopičenih vzorcev, ki služijo kot mehanizem mentalne ekonomije, deluje $v$ osnovi na podoben način tudi $v$ primeru dozdevno različnih in težjih situacij za reševanje.

Vrednost mentalne ekonomije za posameznika narašča s staranjem. Sleherni posameznik ima določeno količino mentalnih virov. Kaj pri nekem posamezniku opredeljuje količino teh virov, ki variirajo od osebe do osebe, natančno (še) ne vemo, vendar vemo, da omogoča mentalna ekonomija, ki temelji na mehanizmih prepoznavanja vzorcev, reševanje zelo zapletenih mentalnih nalog z minimalno porabo mentalnih virov. Mentalna ekonomija prepoznavanja vzorcev deluje proti upadanju mentalnih virov, ki se pri večini ljudi pojavlja med staranjem.

Prav tako so splošni spomini sredstva za prepoznavanje vzorcev. Kot je ugotovil Simon (1996), je prepoznavanje vzorcev najbolj splošno in najbolj učinkovito sredstvo za reševanje problemov, ki nam je na razpolago. Čim več splošni vzorci prispevajo k takojšnji rešitvi vrste pomembnih problemov brez prizadevanj, tem bolj predstavljajo elemente modrosti. Čim bolj splošni so, tem bolj redundantne so njihove nevronske predstavitve in tem bolj so odporni proti učinkom slabšanja možganov in demence. Čim pogosteje te vzorce med mentalnimi aktivnostmi aktiviramo, manj so elementi modrosti ranljivi na učinke kognitivnega upadanja. Repertoar vzorcev raste s staranjem, in tako je staranje cena, ki jo moramo plačati za kopičenje vzorcev modrosti (Goldberg, 2007).

$V$ naši kulturi prevladuje močno nagnjenje $\mathrm{h}$ končnim taksonomijam, popolnim dihotomijam in binarnim razlikam. Vendar je realnost pogosteje nepretrgana in razdeljena po stopnjah kakor razmejena z izrazitimi mejami. Razlike med modrostjo in kompetentnostjo niso izrazite. 
Kot rečeno, prihajata modrost in kompetentnost s staranjem. Vendar je modrost nagrada, plačilo, ki ga je treba zaslužiti, in ne pravica, podobno kot moramo delati za pridobivanje kompetenc. Če to prevedemo v jezik možganov - pravi Goldberg - modrost in kompetentnost pridobimo skozi akumulacijo atraktorjev, ki omogočajo prepoznavanje vzorcev $v$ pomembnih situacijah. Vsako človeško bitje kopiči določeno zmogljivost tekom svojega življenja. Toda vsak posameznik ne uspe nabrati vzorcev, potrebnih za reševanje problemov pristne pomembnosti za veliko drugih ljudi. Na splošno povedano, to uspe ljudem, ki so porabili svoje življenje za spoprijemanje s težkimi mentalnimi izzivi in so bili pri tem uspešni. Z drugimi besedami povedano, bistri ljudje, ki so bili tudi mentalno aktivni v večjem delu svojih življenj, so nagrajeni z izjemno mentalno odpornostjo proti učinkom staranja.

Znanje in kompetence se kažejo v tacitnem znanju, vrsti proceduralnega znanja, potrebnega pri reševanju problemov na delovnem mestu. Tacitno znanje ni izrecno naučeno kot del formalnega izobraževanja, dejansko pa tacitno znanje manj propada kot izolirane mentalne sposobnosti (spomin, pozornost itd.), ki se običajno merijo s formalnimi nevropsihološkimi testi. To pomeni, da bo star strokovnjak pri delu zanesljiv navkljub upadanju spomina in koncentracije - je dokončna ugotovitev Elkhonona Goldberga.

Tacitno znanje se nanaša predvsem na reševanje problemov, ne na znanje dejstev. To nas pelje k pomembni distinkciji: razliki med opisnim (deskriptivnim) in predpisnim (preskriptivnim) vidikom mišljenja ter med opisnim in predpisnim vidikom modrosti in kompetentnosti. Temu ustreza tudi mehanizem prepoznavanja vzorcev, ki je utelešen v atraktorjih. Opisno znanje je znanje o tem, kakšne stvari so. Včasih ga imenujemo tudi znanje resnice. Navedbe so lahko resnične ali lažne. Predpisno znanje ni znanje o tem, kakšne stvari so, pač pa o tem, kakšne naj bi bile. Zlasti gre za znanje o tem, kaj moramo narediti, da stvari prilagodimo svojim željam in potrebam. $V$ tem smislu je predpisno znanje odvisno od nas. To je znanje o naših potrebah in o smeri dejanj, ki je za nas najboljša. Izbira dejanja je za različne ljudi različna, kar Goldberg (2007) včasih poimenuje "na atraktorja usmerjeno znanje» (angl. actor-centred knowledge).

Ljudje smo naravnani na močne mentalne mehanizme, ki nam omogočajo pridobivanje in shranjevanje opisnega znanja, vendar so ti mehanizmi sekundarni, pomožni, podrejeni našim potrebam za pridobivanje in shranjevanje predpisnega znanja. Evolucijske nujnosti, ki so oblikovale naše možgane in naše telo, so bile naravnane na izboljšavo našega preživetja, in ne na našo sposobnost ugotavljanja dokončne resnice, čeprav spoznanje objektivne resnice prispeva k izboljšavi sposobnosti preživetja. Opisno znanje (znanje resnice) je sredstvo za doseganje ciljev preživetja in ni namen sam zase. Kognitivni psihologi so (bili) praviloma usmerjeni k razumevanju mehanizmov opisnega znanja. Mehanizmi predpisnega znanja so šele pred kratkim začeli pritegovati primerno znanstveno zanimanje, ki si ga zaslužijo. Zatorej ne preseneča, da se predvsem cenijo predpisno znanje, predpisna modrost in predpisna kompetentnost. Ljudje se k starejši osebi ali strokovnjaku obračamo bolj zaradi nasveta, kaj storiti, kakor zaradi pojasnjevanja o tem, kakšne stvari so. Modrost in kompetentnost imata veliko predpisno moč.

Možgane sestavljata leva in desna hemisfera. Funkcionalno je pomembna tudi delitev na sprednje in zadnje dele možganov. Tako opisno kot tudi predpisno znanje temelji na prepoznavanju vzorcev, vzorci pa so utelešeni v atraktorjih. Znanje je namreč shranjeno tam, kjer so bile informacije najprej obdelane (Pomni: Prostorsko ločenih skladišč spominov $v$ možganih ni.). Atraktorji, v katerih je utelešeno opisno in predpisno znanje, naseljujejo različne 
neokortikalne teritorije. Tako opisno kot predpisno znanje je shranjeno v asociacijskih predelih neokorteksa. Opisno znanje je shranjeno večinoma v asociacijskih področjih temporalnega, parietalnega in okcipitalnega režnja. Sodobne raziskave so tudi pokazale, da igrata dve cerebralni hemisferi zelo različne vloge pri pridobivanju in shranjevanju znanja, v oblikovanju atraktorjev in $v$ mehanizmih prepoznavanja vzorcev.

Kognitivni razvoj in kognitivno staranje sta povezana z dozorevanjem frontalnih režnjev in njihovim propadanjem. Frontalni režnji, ali natančneje, prefrontalni korteks je za preostale možgane tisto, kar je dirigent za orkester. Prav tako kot dirigent ne igra nobenega glasbila, tudi frontalni režnji niso pristojni za nobeno posebno mentalno sposobnost. Simfonična glasba se ne dogaja znotraj katerega koli od instrumentov, ki sodelujejo pri koncertu. Tisti, ki jih združuje in povezuje, je dirigent.

Temu je podobno zapleteno ravnanje, ki je odvisno od več kot ene mentalne sposobnosti, frontalni režnji pa so tisti, ki organizirajo naše mentalne sposobnosti v zapletene ansamble. Frontalni režnji so odgovorni za načrtovanje in kartiranje stez, ki jih mora organizem uporabiti pri reševanju vrste problemov. To upravljalno vlogo frontalnih režnjev pogosto poimenujemo izvršilna funkcija (angl. executive function) po analogiji z generalnim izvršnim direktorjem (angl. Chief Executive Officer, CEO), ki je odgovoren za korporativne strategije. To je tisto, kar počnejo frontalni režnji $v$ živem biološkem organizmu. Notranja organizacija prefrontalnega korteksa ima hierarhično strukturo s poveljstvom v zgornjem delu in drugimi deli spodaj. Sprednji del prefrontalnega korteksa je pristojen za odločanje $v$ celoti. Območja za prefrontalnim korteksom so odgovorna za načrtovanje in izvrševanje vedno podrobnejših delov celotne naloge. Več izmed bolj sistematičnih miselnih procesov je odvisnih od frontalnih režnjev. Indukcija terja več prefrontalnih virov kakor dedukcija. $V$ prefrontalnih režnjih so spomini načrtov, spomini prejšnjih »izvršilnih« rešitev za različne probleme in mentalne navade za racionalno analizo, ki smo jo razvili sčasoma. To so izvršilni spomini. Predpisno znanje, splošni spomini učinkovitih načinov pristopanja k življenjskim situacijam in optimalnim smerem dejanj za celotne razrede takih situacij se nabirajo znotraj frontalnih režnjev. Modrost in ekspertnost sta namreč posebno pomembni za predpisno moč prefrontalnih režnjev, zato so ti zelo pomemben del nevronskih mehanizmov modrosti in ekspertnosti.

\subsection{Nevroznanstveni vidik}

V sodobnih raziskavah na področju nevroznanosti je poudarek premaknjen s proučevanja opisnega mišljenja in znanja na proučevanje predpisnega mišljenja in znanja, torej tistega, kar je najbolje zame. $V$ primeru predpisnega znanja gre za sposobnost uporabe znanja za upravljanje lastnega ravnanja.

Danes so proučevanja usmerjena na frontalne režnje možganov, saj vključujejo nevronske mehanizme predpisnega znanja, ki so najmlajši rezultati evolucije. Naloga frontalnih režnjev je tudi ščititi svoje skrivnosti. Vloga frontalnih režnjev je tako velika, da jih pogosto imenujejo metakognitivni režnji, ne zgolj preprosto kognitivni. To velja za prefrontalni korteks, ne pa za frontalni reženj $v$ celoti. Vzpon prefrontalnega korteksa $v$ evoluciji je razmeroma novejšega datuma, višjo raven razvoja je dosegel samo pri sesalcih, eksponenten razvoj pa je imel le pri višjih primatih. 
Lurija (1966) je prefrontalni korteks razglasil za organ civilizacije; človek je tisto, kar je nastalo po razvoju frontalnih režnjev. Pacienti s poškodovanimi frontalnimi režnji nimajo sposobnosti oblikovanja vpogleda v notranje svetove drugih ljudi in sposobnosti moralnega razsojanja.

Po Goldbergu (2007) je prefrontalni korteks samo indirektno odgovoren za oblikovanje etičnih pojmov in moralnosti, in sicer za vlogo prefrontalnega korteksa pri oblikovanju odnosa med prej in potem (časovna razmerja), za še bolj abstraktna kavzalna razmerja med vzrokom in posledicami. Razviti prefrontalni korteks je najverjetneje potreben za oblikovanje celega razreda odnosov tipa če - tedaj (angl. if - then). Ta sposobnost je mejnik številnih zapletenih kognitivnih sposobnosti.

Moralno razsojanje je vrsta odločanja. Je zmožnost predstavljanja posledic alternativnih smeri dejanj (Kaj bi se zgodilo, če naredimo $X$ namesto $Y$ ?) in zmožnost kesanja, kadar pridemo do zaključka, da smo se na križičču odločili za napačno smer. Danes vemo, da sta sposobnost nasprotnega rezoniranja in zmožnost izkušnje kesanja odvisni od frontalnih režnjev. Pacienti s poškodovanimi določenimi deli frontalnih režnjev (orbitofrontalni korteks) v znatni meri izgubijo ti sposobnosti.

Empatija, vpogled $v$ duhove drugih in zmožnost moralnega razsojanja spadajo med najpomembnejše sestavine modrosti po kateri koli definiciji; te zmožnosti so enakovredne $z$ zmožnostjo uspešnega odločanja ( $v$ ekonomski, politični in zasebni sferi). Po številnih definicijah modrost vključuje sposobnost povezovanja pragmatičnih in na aktorja usmerjenih ter etičnih in z empatijo vodenih premišljevanj, kar je bistvo modrosti. Enkratna vloga prefrontalnega režnja je $v$ zagotavljanju nevronskih mehanizmov za povezovanje teh dveh dejavnikov $v$ enoten, dobro integriran proces odločanja.

Popolnoma funkcionalno razviti frontalni režnji so predpogoj socialne zrelosti. $V$ tem hipu je nevrobiologija individualnih razlik še v svoji otroški dobi razvoja. Predmet individualnih razlik so lahko teža, višina, barva oči, las, zmogljivost ledvic itn. Koliko različnih talentov imamo, je v veliki meri odvisno od individualnih razlik, ki so značilne za naše možgane. Frontalni režnji so bolj občutljivi na učinke staranja kakor večina drugih delov možganov, vendar to ne pomeni, da predpisna modrost $s$ staranjem izginja. Prav tako to tudi ne pomeni, da je propadanje frontalnih režnjev pri vsaki osebi enako.

Prefrontalni korteks je repozitorij za semantični izvršilni spomin in za spomin za koncepte dejanj (Fuster, 2003). Ti spomini se namreč razlikujejo po splošnosti, organizirani pa so hierarhično. Podobno kot drugi splošni spomini so izvršilni splošni spomini razmeroma neranljivi na učinke poškodb možganov. To npr. staremu političnemu vodji omogoča, da pri izvajanju svojih nalog ostane uspešen kljub kognitivnemu propadanju sposobnosti izvajanja novih mentalnih izračunov. Ljudje z izvršilno inteligentnostjo skozi življenje nakopičijo veliko nevronsko knjižnico splošnih izvršilnih spominov, spominov prejšnjih uspešnih rešitev težkih problemov v obliki atraktorjev, ki so $v$ celoti ali delno $v$ frontalnih režnjih, in obstaja velika verjetnost, da bodo uspešno reševali tudi nove težke situacije na osnovi podobnosti med novimi in starimi situacijami.

Izvršilna inteligentnost in emocionalna inteligentnost nista čisto identični, a sta tesno povezani. Njun sedež je $v$ frontalnih režnjih. Emocionalna inteligentnost obvešča izvršilne spomine znotraj frontalnih režnjev. Staranje frontalnih režnjev je individualno. Večja funkcionalna dolgoživost frontalnih režnjev je najbrž pomemben ključ za zdrav duh v poznih 
letih starosti. Osebe, ki so ohranile dobro delovno kondicijo svojih prefrontalnih režnjev, imajo dobre možnosti, da zadržijo zdravo pamet v starosti. Študije so pokazale, da imajo zelo aktivni starejši posamezniki fiziološko aktivnejše frontalne režnje. Mentalna aktivnost in mentalno prizadevanje krepita nevronsko tkivo. Tako imajo ljudje z dolgoživo zgodovino zapletenega izvršilnega odločanja boljše možnosti ohraniti nevronsko integriteto svojih frontalnih režnjev tudi v starosti kot pa pasivni "spremljevalci«, ki so si v mlajši dobi le v razmeroma skromni meri prizadevali izvajati svoje izvršilne funkcije.

Premik izvršilnih talentov in inteligentnosti iz Platonove duše v področje bioloških možganov vključuje veliko pomembnih posledic. Podobno kot pri vsakem drugem biološko utemeljenem atributu duha tudi darilo izvršilnega talenta ni porazdeljeno $v$ enaki meri med vsemi. Potemtakem je dobra selekcija naravnih talentov, ki jo izvajajo atletski trenerji, koreografi in glasbeni učitelji, ključ za uspeh, bolj kot vse drugo. Študije so pokazale, da najuspešnejši korporativni izvrševalci običajno nimajo izjemnega inteligenčnega kvocienta. Njihovi inteligenčni kvocienti so častivredni znotraj razpona, ki ga poimenujemo visoko povprečje do izjemno dobro, vendar pa niti približno niso nad tem merilom. Pacienti s težko poškodbo frontalnega režnja imajo pogosto normalen inteligenčni kvocient, čeprav je njihova zmogljivost tehtnega vedenja popolnoma uničena.

Izvršilne funkcije so mnogolične, zato edinstveno merilo ni mogoče. Potrebujemo večkratne meritve oz. ločeno merjenje sposobnosti načrtovanja, mentalne koncentracije, mentalne fleksibilnosti, empatije in sposobnosti za ukvarjanje z novimi situacijami in problemi ter sposobnosti za razumevanje drugih, ki je bistvena za altruistične kooperativne in tekmovalne situacije.

Genialnost/talent in modrost/kompetentnost sta dve med seboj nepovezani nadarjenosti in ena lahko obstaja brez druge. Kompetentnost in njena najvišja oblika modrost sta odvisni od sposobnosti prepoznavanja vzorcev, ki vključujejo deskriptivne in preskriptivne informacije. Dvojnost je univerzalna lastnost možganov na vseh ravneh - od možganskega drevesa do neokorteksa. Za vsako strukturo obstaja dvojnik. Nekoč smo si to dvojnost predstavljali kot popolno simetrijo. Danes vemo, da je simetrija možganov le približna in delna. Resnica je, da so možgani bolj simetrični kot asimetrični. Resnica je tudi, da obe polovici ne delujeta izolirano ena od druge; povezani sta z veliko stez na vseh ravneh, in to tako na kortikalni kot na subkortikalni ravni. Na kortikalni ravni so steze, ki povezujejo hemisferi, organizirane $v$ veliko strukturo, ki se imenuje kalozni korpus, ter sprednjo in zadnjo komisuro. Te in druge steze zagotavljajo tekoče komuniciranje med hemisferami. Načelo dvojnosti se ne nanaša le na endokrine žleze.

Številne teorije in hipoteze poskušajo pojasniti dualizem človeških možganov. Novi znanstveni dokazi terjajo popolnoma novo razumevanje dualnosti možganov. Po prejšnji (napačni) teoriji je leva hemisfera odgovorna za jezik, desna pa za vidno-prostorske oz. neverbalne procese. Vendar smo ljudje edina vrsta, ki uporablja jezik ( $v$ ožjem pomenu besede), in smo torej edina vrsta, za katero je razlikovanje med jezikom in neverbalnimi funkcijami sploh smiselno. Ta zaključek bije mrtvaški zvon teoriji jezikovne in neverbalne specializacije hemisfer. Vedno bolj je jasno, da potrebujemo nov konceptualni okvir, premik paradigme o našem razumevanju dualizma možganov. 
Goldberg (2007) je zastavil teorijo novost-rutina, po kateri je pojasnil funkcionalne razlike med hemisferami. Pri desničarjih je leva hemisfera odgovorna za kognitivne rutine, desna pa za nove informacije. Njegova teorija vključuje tudi tekoče spremembe $v$ naravi interakcij med obema stranema možganov. Kar je novo danes, bo znano jutri, po enem tednu ali po enem letu. Oblikovali se bodo ustrezni vzorci in problem, ki ga danes lahko rešimo z velikim prizadevanjem in velikim mentalnim naporom, bomo pravočasno rešili na osnovi takojšnjega prepoznavanja vzorcev.

Po tradicionalni nevropsihologiji je funkcionalna organizacija vseh človeških možganov enaka. Vendar - kar je novo za eno osebo, je znano za drugo osebo. Zato vključuje Goldbergova teorija višjo stopnjo individualnih razlik glede na načine, na katere funkcionirajo naši možgani, kot je bilo kadar koli prej. Vsak proces oblikovanja novega vzorca - bodisi da je opisni (učenje novih pojmov) ali predpisni (učenje, kako rešiti novi razred problemov) - mora najprej angažirati desno hemisfero in potem levo hemisfero. Obstajati mora postopni premik mentalnega središča gravitacije in smer tega premika mora biti predvidljiv, ustrezen in enosmeren z desne na levo.

Teorija novost-rutina lahko vsaj načelno prispeva k razrešitvi skrivnosti možganskega dualizma skozi evolucijo sesalcev, saj velja distribucija med novim in znanim tudi za vsa bitja $\mathrm{s}$ sposobnostjo učenja. Desna hemisfera je dominantna pri neizkušenem posamezniku med zgodnjimi stadiji pridobivanja kognitivnih sposobnosti, vendar pa leva hemisfera z razvojem sposobnosti prevzema dominantno vlogo. Prenos $z$ desne na levo je univerzalno pravilo, ki velja za vse kognitivne naloge od verbalnih do vidno-prostorskih in za vsa časovna merila - od ur do desetletij. Pri novincih, ki pridobivajo nove sposobnosti, je dominantna aktivnost desne hemisfere. Pri izobraženih strokovnjakih, ki izvajajo iste naloge, pa je dominantna aktivnost leve hemisfere. Tako tudi jezik ni monopol leve hemisfere. Pri majhnih otrocih ima pomembno vlogo med učenjem jezika desna hemisfera. Enako velja za rešitve problema tipa hevreka.

Možgani različno obdelujejo materinščino in tuj jezik. Možganski mehanizmi za jezik niso niti statični niti niso vezani na iste dele možganov. Različne stopnje jezikovnega razvoja so vezane na konstelacije različnih regij možganov. Vloga desne hemisfere za jezik s staranjem postopno upada in je $v$ možganih odrasle osebe razmeroma omejena. Splošno načelo organizacije možganov se glasi, da je desna hemisfera odgovorna za nove informacije, leva pa za dobro oblikovane kognitivne sposobnosti. Če je jezik razmeroma novo kognitivno sredstvo, kot je v primeru prvega jezika pri otroku in drugega jezika pri odrasli osebi, igra pri učenju ključno vlogo desna hemisfera. Ko pa je jezik enkrat naučen, ga postopno monopolizira leva hemisfera. Leva hemisfera je sedež vseh vrst splošnih vzorcev, tako tistih, ki so v zvezi z jezikom, kot tistih, ki niso povezani z jezikom. $V$ levi hemisferi so razen opisnih shranjeni tudi predpisni vzorci.

Desna hemisfera je zavedno odgovorna za nekatere kategorije odločanja, kot sta družbeno razsojanje in sposobnost upravljanja medosebnih odnosov, saj za ti dve kategoriji ne obstajajo dokončni vzorci. Pri teh kategorijah je vedno nekaj novega in posameznik mora nepretrgoma improvizirati. Socialne situacije so namreč preveč različne, preveč fluidne in komaj opazne za kodifikacijo skozi določeno število vzorcev.

Proces prenosa kognitivne kontrole je različen za različne kognitivne sposobnosti. Vendar ne gre za en enovit proces, za en velik premik z desne na levo, ampak za mnogoštevilne procese, ki se odvijajo istočasno ali v različnem času in pri različni hitrosti. S staranjem se odvija premik 
središča kognitivne gravitacije $z$ desne na levo stran možganov. Pri mlajši odrasli osebi je desni prefrontalni korteks bolj aktiven kot levi. Pri starejši odrasli osebi postaja levi prefrontalni korteks vedno bolj aktiven.

Razlike $v$ predstavitvi znanja $v$ hemisferah ustrezajo njihovim različnim vlogam $v$ različnih stopnjah učenja. Isti nabor podatkov si lahko predstavljamo na dva različna načina:

- kot skupek podatkov (Skupek podatkov vključuje subjekte, njihove lastnosti in odnose, npr. predstavitev podatkov v obliki razpredelnice.);

- kot oblak (angl. cloud) podatkov oz. podatkovnih točk (Oblak omogoča shranjevanje ter zagotavlja zaščito in dostopnost velike množice različnih vrst podatkov v digitalni obliki za uporabnike ne glede na njihovo kategorijo, število, kraj in čas, npr. oblak vladnih podatkov za državljana.).

Prva predstavitev je skupina povprečij, ki zajema bistvo totalitete vseh prejšnjih izkušenj, vendar brez podrobnosti. Druga predstavitev je knjižnica posamičnih izkušenj, vendar brez možnosti, da izvlečemo bistvene posplošitve. Skupek podatkov prikazujemo na osnovi povprečij in standardnih deviacij - na ta način je znanje prikazano $v$ desni hemisferi. Posamezne podatkovne točke prikazujemo $z$ uporabo grafičnega prikaza, $v$ katerem vsaka podatkovna točka predstavlja posebne lastnosti ozkega razreda situacij - tako je znanje prikazano v levi hemisferi. Gre za hevristično metaforo, in ne za dobesedni opis. Če je kognitivni izziv prepoznan kot znan, bodo levi možgani izvedli obdelavo v skladu s prejšnjimi izkušnjami, ki so značilne za ta tip situacije. Če pa je kognitivni izziv prepoznan kot nov, je edini način za obdelavo situacije uporaba privzetih "povprečnih« informacij, vsebovanih v desni hemisferi.

S staranjem nabiramo splošne spomine, ki omogočajo vedno večjo uporabo sposobnosti koriščenja bližnjic pri reševanju problemov, s čimer se izognemo napornemu mentalnemu delu, potrebnemu za razvozlavanje novih kognitivnih izzivov in za zgostitev tega dela v obliki prepoznavanja vzorcev. Knjižnica vzorcev se polni skozi celotno življenjsko obdobje. Vzorci se shranjujejo $v$ levi hemisferi. S staranjem se vedno več opiramo na levo hemisfero in vedno manj na desno. $S$ kopičenjem vzorcev se razmerje uporabe hemisfer premika neizprosno od desne hemisfere proti levi.

Za ukvarjanje s kognitivnimi novostmi so poleg desne hemisfere pomembni frontalni režnji, tj. prefrontalni korteks. Pri zelo kreativnih osebah je pri reševanju problemov prisotna bilateralna aktivnost obeh hemisfer, pri manj kreativnih osebah pa sodeluje samo leva hemisfera. Nevrobiologija čustev je ugotovila delitev dela med hemisferami, po kateri je leva (levi prefrontalni korteks) vključena $v$ pozitivne emocije, desna (desni prefrontalni korteks) pa $v$ negativne.

Naš notranji svet vključuje dihotomijo:

- notranji svet emocij, ki ga upravljajo "vroče« filogenetske stare subkortikalne strukture, in

- notranji miselni svet, ki ga upravlja »hladni« neokorteks.

Mehanizmi emocij se začnejo pojavljati v zgodnjih fazah evolucije. Neokorteks - najmlajši del možganov - je vključen $v$ brezstrastno, razumsko, čustveno prazno premišljanje. Leva 
hemisfera je, kot rečeno, povezana z jezikom. Kajti jezik je zelo pomembna in vse objemajoča sposobnost, izguba za človeka ne more ostati neopazna in postaja vir velike stiske. Nasprotno pa so funkcije desne hemisfere bolj varljive in manj dostopne za introspekcijo. Ljudje (pacienti) se običajno manj zavedajo izgube teh funkcij in njihova izguba jih manj pretresa. $V$ primeru poškodbe desne hemisfere pacient kaže osupljivo nezavedanje primanjkljaja, pojav je znan kot anozognozija. Avreola blaženosti, ki prihaja od ravnodušnosti pri teh pacientih, je v popolnem nasprotju z žalostno stvarnostjo katastrofične poškodbe možganov, ki so jo utrpeli. Anozognozija pogosto poprime obliko leve polzanemarjenosti, okoliščina, ki se pojavi, ko možgani ne uspejo ustrezno zabeležiti in obdelati informacij, ki prihajajo iz leve polovice zunanjega sveta. Vzrok temu pojavu je, da se senzorne steze, ki $v$ možgane prenašajo informacije o zunanjem svetu, večinoma križajo. Informacije o levi polovici sveta se pošiljajo $v$ desno hemisfero, informacije o desni polovici sveta pa v levo hemisfero. Ko poškodba zadene levo stran možganov, pacient običajno brez težav odkrije prizadetost in izve, kako jo nadomestiti. Če pa poškodba zadene desno stran možganov, se pacient pogosto ne zaveda posledic in ne stori ničesar, da bi to prizadetost nadomestil, in leva polzanemarjenost postane huda in trajna. Ta pojav ni omejen le na vizualne čute. Lahko so prizadeti tudi taktilni čuti, kar povzroča sindrom tuje roke. Pacient $s$ tako poškodbo bo čutil levo stran svojega lastnega telesa, kot da pripada drugi osebi, in se bo spraševal, kaj tuja roka počne zraven njega, in ne bo niti najmanj skrbel za svoje lastno nevrološko stanje. In obratno: pacient z afazijo, ki jo je povzročil udar na levi hemisferi, se običajno jasno zaveda svoje prizadetosti, in to ga muči, plaši in žalosti. Depresija pri takem pacientu je reakcija na kognitivni primanjkljaj. Takih stanj in prizadetosti je še več.

PET in fMRI sta omogočila neposrednejši vpogled $v$ odnose med čustvenimi stanji in stranmi možganov pri normalnih ljudeh. Film in slike, ki vsebujejo prijetne informacije, povzročajo naraščanje aktivacije v levi hemisferi oz. levem prefrontalnem korteksu. In obratno: Če osebi pokažemo neprijetne ali žalostne slike, narašča aktivacija $v$ desni hemisferi. Študije poškodb možganov skupaj s študijami z uporabo sodobnih tehnologij za opazovanje nevronskih stanj pri normalnih ljudeh kažejo, da igrata obe hemisferi predvsem nasprotni vlogi v izkušnjah in izražanju emocij. Čustvene izkušnje in izražanja se ne smejo mešati s sposobnostjo prepoznavanja in razlikovanja emocionalnih izražanj pri drugih ljudeh.

Posamezniki se razlikujemo glede na elektro-fiziološke lastnosti in emocionalni slog. Leva frontalna področja možganov so bolj aktivna pri veselih osebah, desna frontalna področja možganov pa pri osebah, ki se nagibajo k negativnim čustvom in depresiji. Boleče negativne emocionalne reakcije na socialno izključevanje vključujejo desni frontalni korteks (Eisenberger, Liebesman in Williams, 2003). Delitev dela med hemisferama pri urejanju čustev ni omejena na neokorteks in vključuje tudi filogenetsko staro subkortikalno strukturo (amigdale). Goldbergova teorija novost-rutina povezuje kognitivne in emocionalne vidike specializacije hemisfer. Obstaja bistvena povezanost kognitivnih rutin in pozitivnih čustev, ki se dogajajo v levi hemisferi, ter novosti in negativnih čustev, ki se dogajajo $v$ desni hemisferi. Pravokotna (ortogonalna) specializacija hemisfer naj ne bi bila naključna.

Pri pripustitvi informacij $v$ dolgoročni spomin so možgani visokoselektivni. Molekularne osnove spomina je raziskoval ameriško-avstrijski nevroznanstvenik Eric Richard Kandel, ki je leta 2000 skupaj z Arvidom Carlssonom in Paulom Greengardom prejel Nobelovo nagrado za fiziologijo in medicino - Kandel za opis delovanja kratkoročnega in dolgoročnega spomina na 
molekulski ravni, Carlsson za dokaz, da je dopamin živčni prenašalec (nevrotransmiter) v možganih, katerega pomanjkanje se izraža s simptomi Alzheimerjeve bolezni, Greengard pa za odkritje, kako dopamin in drugi nevrotransmiterji delujejo na celico v živčnem sistemu, pri čemer aktivirajo centralno molekulo, znano kot DARPP-32.

V dolgoročni spomin spadajo informacije, ki so potrdile svojo koristnost čez daljše časovno obdobje, in ne informacije trivialnega pomena, kot je npr., kaj smo imeli za kosilo predvčerajšnjim. Vsebina skladišča v levi hemisferi sestoji pretežno iz koristnih informacij, ki so po svoji uporabnosti dobre za organizem. Desna hemisfera se ukvarja z novostmi. Novi problemi, ki jih ne moremo rešiti na osnovi obstoječega repertoarja vzorcev v levi hemisferi, pa terjajo novo preučevanje. Iskanje nove rešitve sproži nezadovoljstvo z (do)sedanjim stanjem. Nezadovoljstvo sproži tudi situacija, ki ni prijetna oz. je slaba za organizem. Možganska biokemija nevrotransmiterjev kognitivnih in emocionalnih vidikov specializacije hemisfer je tesno povezana. Transmiter dopamine $v$ levi hemisferi sproži kognitivne rutine in pozitivna čustva. Nevrotransmiter norepinephrine pa posreduje raziskovalno vedenje. Abnormalna raven tega nevrotransmiterja posreduje negativne emocije. Upad serotonina, ki je povezan z depresijo, povzroča kognitivno nefleksibilnost, kar tudi kaže na enotnost kognitivnih procesov in čustvenih stanj. Funkcija prefrontalnega korteksa je predvsem izračunati, kaj je dobro za organizem, ne pa, kaj je resnica $v$ abstraktnem smislu besede. Prefrontalni korteks je posebej aktiven med čustvenimi izkušnjami. Na podlagi tega Goldberg (2007) zaključuje, da je povezanost levega in desnega možganskega korteksa s čustvenimi stanji sekundarna glede na kognitivne funkcije, ki so $v$ tem primeru primarne funkcije.

Možgani urejajo čustva skozi sočasno povezovanje vertikalnih in horizontalnih krogov. Emocionalno reakcijo sprožita dva inputa: eden je razumsko kortikalni, drugi pa nagonsko subkortikalni, spajata pa se $v$ front-subkortikalne kroge in vzpostavljata vertikalno integracijo emocij. Integracija pozitivnih levih in negativnih desnih front-subkortikalnih krogov prek kaloznega korpusa in sprednje komisure proizvaja hkrati horizontalno integracijo čustev. Posamezniki imamo različne čustvene in kognitivne sloge. Kreativnost in genialnost sta npr. povezani s psihiatrično obolelostjo (manično-depresivnimi bipolarnimi motnjami). Zdravi ljudje $z$ umetniško nadarjenostjo in kreativnostjo imajo bolj izražene simptome srednje manično-depresivne bipolarne motnje kot drugi zdravi ljudje.

Vzorci možganske aktivacije se pri istem pacientu med maničnimi in depresivnimi stanji zelo razlikujejo. Upiranje mladine naj bi predstavljalo dramatično izražanje čustvenega ravnanja desne hemisfere. $Z$ normalnim staranjem se (optimalno) čustveno ravnanje spreminja. $V$ drugi polovici življenja so negativna čustva manj poudarjena in prevladujoče čustveno ravnanje postaja bolj pozitivno. Subkortikalne strukture postajajo manj odmevne za čustveno negativne dražljaje, dokler se njihov odgovor na emocionalno pozitivne dražljaje ne spreminja. Prevladuje čustveno ravnanje leve hemisfere.

Razvoj našega duha se od vodilne vloge desne hemisfere $v$ mladosti do vodilne vloge leve hemisfere $v$ starejši dobi odvija skladno skozi večkratne fronte, kognitivne in čustvene, in njihovo enotnost $v$ našem mentalnem življenju in razvoju. Modrost je na zelo zapleten način povezana s spominom (spominski varni pas, izpostavljenost nevarnosti spomina), in sicer $\mathrm{s}$ splošnim spominom, ki je tesno povezan z vzorci in procesi, ki se oblikujejo v možganih. 
Spomin se pretežno oblikuje in shranjuje $v$ najmlajšem delu možganov $-v$ neokorteksu. Določeni spomini potrebujejo podporo različnih subkortikalnih struktur, drugi spomini pa te podpore ne potrebujejo. Spomini, ki so odvisni od takih dodatnih struktur, so zelo ranljivi za propad in učinke nevroloških bolezni. Nasprotno pa so spomini, ki so odvisni od neokorteksa in niso odvisni od dodatnih struktur zunaj neokorteksa, razmeroma odporni proti propadu in lahko dlje časa sobivajo z nevrološkim upadanjem, celo z demenco.

Propad spomina trivialnih in nepomembnih dogodkov je rešitev, saj bi bilo drugače koristno znanje prekrito z velikansko količino nekoristnih informacij - informacijskim šumom, informacijskimi smetmi in odpadki. Normalen dolgoročni spomin je zelo selektiven, vendar pa poškodbe možganov povzročijo pozabljanje selektivnega spomina - amnezijo, ki predstavlja bolezen $v$ različnih oblikah (benigno pozabljanje pri starih ljudeh, katastrofično pomanjkanje spomina itd.).

Spomin je prejemanje in obdelava novih informacij $v$ vključenih nevronskih mrežah. Sintetizirajo se nove beljakovine, razvijajo nove sinapse (kontakti med nevroni), druge sinapse pa se krepijo v sorazmerju s sinapsami, ki jih obkrožajo. Spomin se oblikuje vedno $v$ istih možganskih strukturah in vključuje iste nevronske mreže, ki sodelujejo in obdelujejo informacije po vrstnem redu prihoda. Spomin se ne seli, temveč ostaja tam, kjer je nastal.

Ko postanejo kemijske in strukturne spremembe $v$ določeni mreži trajne in močne, se informacije ugnezdijo $v$ dolgoročni pomnilnik. Kontakti $v$ sinapsah se zamenjajo in oblikujejo se novi receptorji. Tako oblikovan spomin je močan in razmeroma neranljiv za možganske udare - travmatske poškodbe, virusne infekcije možganov ali demenco. Spominski procesi morajo pomagati določenim drugim strukturam v možganih, da spomin doseže stadij močnega kodiranja (angl. encoding). Vloga teh struktur je reaktivacija kritičnih nevronskih mrež v neokorteksu, kjer se postopoma dogajajo kemijske in strukturne spremembe, čeprav je dražljaj zdavnaj izginil. Procesi reaktivacije $v$ teku so električni in vključujejo zanke ponavljajočih se bioelektričnih aktivnosti v možganih, znane tudi kot ponavljajoči se vnos (angl. reentry).

Nekatere od teh zank so oddaljene in vključujejo več oddaljenih regij. Ti procesi se imenujejo odmev ali ciklični ponavljajoči se vnos. To se dogaja, ko nekaj ponavljamo, da ne pozabimo, npr. telefonsko številko, ki je nismo uspeli zapisati. Vendar so zanke odmeva zelo občutljive in nestabilne ter jih lahko prekinejo številni fiziološki procesi v možganih.

Razširjanje zank odmeva je odvisno od številnih možganskih struktur zunaj neokorteksa, ki vključujejo hipokampuse in obkrožujoče strukture ter možgansko deblo. Hipokampusi in druge strukture so izjemno pomembni za oblikovanje dolgoročnih spominov, ostati morajo aktivni tako dolgo kakor zanke odmeva. Ta področja so namreč zelo ranljiva na učinke demence; pred tem se je verjelo, da so hipokampusi sedež spominov - kot da bi rekli, da je sedež informacij v baterijah, ne pa v računalniku, vendar brez baterij novih informacij ni možno shraniti na trdem disku.

Ko je spomin enkrat trdno ugnezden $v$ dolgoročno skladišče, se vloga hipokampusov pri vzdrževanju drastično zmanjšuje. Spomini, ki so postali dolgoročni, niso več odvisni od ponavljajočih se električnih zank in električni šoki za utrjevanje spomina (npr. z učenjem pridobljena spretnost) jih ne morejo uničiti. Spomini, ki so se obdržali tri leta po učenju, kažejo majhno količino nadaljnjih izgub. Ti spomini so bili vneseni v dolgoročni pomnilnik, zahvaljujoč 
oblikovanju strukturne spominske sledi. Časovno obdobje za oblikovanje takih sledi znaša več let. Spomini, ki se odložijo v dolgoročnem pomnilniku, nastajajo med 10. in 30. letom starosti, ki predstavlja obdobje pridobivanja najpomembnejšega znanja, ki je osnova za vseživljenjske sposobnosti prepoznavanja vzorcev.

Retrogradna amnezija s fenomenom časovnega gradienta je tudi značilna za demenco. Časovni gradient pomeni, da se bo amnezija nanašala na 1-2 leti po poškodbi v primeru prometne nesreče, spomin na dogodke pred več desetletji pa se bo obdržal. Izguba spomina je lahko posledica psiholoških dejavnikov (npr. histerije). Časovni gradienti kažejo čas, potreben za oblikovanje dolgoročnih spominov. Ablacija hipokampusov ima za posledico retrogradno amnezijo, ki gre do 15 let in več nazaj.

Proces oblikovanja dolgoročnih spominov je postopen in traja več let, celo več desetletij. Potrebno je veliko ponavljajočih se zank, preden ima strukturni možganski vtisk možnost, da se oblikuje. Splošni spomini in vzorci (spomini vzorcev) ne propadajo. Proces oblikovanja spominov je darvinističen: različni spomini tekmujejo za omejen prostor $\mathrm{v}$ skladišču dolgoročnih spominov. Zmaga informacije, ki se pogosteje bori za mesto, in teorija, da selekcijo opredeljuje pomembnost, ne drži, saj znotraj možganov homunkulusa, ki bi upravljal nevronski promet, ni. Pa če bi tudi obstajal, ne bi mogel predvideti, katera informacija je dolgoročno lahko pomembna, saj je pomembnost povečini relativen pojem. Pogostost uporabe je nadomestilo za označevalec za izračun pomembnosti, saj je verjetneje, da bodo pogosteje priklicane posebno primerne informacije; skladno s tem naj bi bile po definiciji pomembne tiste informacije, ki jih pogosteje potrebujemo. Vseeno lahko tudi pomembnost neposredneje uveljavi svoj vpliv na oblikovanje spominov. Če je v luči prejšnjih izkušenj ali gensko opredeljenega trdnega povezovanja določena informacija nemudoma prepoznana kot zelo pomembna, bo amigdala aktivirala samo del ponavljajočih se krogov za oblikovanje spomina. To zelo olajšuje in pospešuje oblikovanje močnih spominov in jim daje prednostno pravico v tekmovanju spominov.

Različne izkušnje $v$ možganih aktivirajo različne nevronske mreže in dveh popolnoma enakih mrež ni. Vendar pa velja, da čim bolj podobne so izkušnje, tem večje je prekrivanje mrež. Skupno jedro med nevronskimi mrežami, ki ga prikličejo podobni, vendar ne nujno popolnoma enaki in posebno pogosti vtisi, imajo možnosti hitrega vnosa $v$ skladišče dolgoročnih spominov. To osnovno obliko procesa učenja v psihologiji imenujemo generalizacija. Skupna mreža, oblikovana na osnovi prekrivanja posebnih mrež, je mentalna predstavitev ne katere koli posamezne stvari ali dogodka, temveč skupne lastnosti nekega razreda podobnih stvari in dogodkov. Tako se oblikujejo splošni spomini v možganih.

Splošni spomini so spomini vzorcev. Tem bolj splošen je vzorec in čim več je izkušenj, na katere se nanaša prekrivanje, tem močnejši in manj ranljiv je vzorec na vplive poškodbe možganov. To pomeni, da so abstraktne predstavitve na splošno sposobnejše sobivati z učinki možganskega upadanja kot konkretne predstavitve, ki se nanašajo na posamezne stvari.

Tipični vzorec poseduje zelo zanimivo lastnost: vsebuje informacije ne samo o stvareh, pač pa tudi informacije o stvareh, ki jih bomo srečali v prihodnje. Vzorec namreč zajema skupne lastnosti in značilnosti vsakega člana razreda stvari ali dogodkov - vseh krompirjev, stolov, viharjev, političnih, finančnih in ekonomskih kriz, vseh diferencialnih enačb, vseh zlomov trga vrednostnih papirjev. Zato nam bo vzorec pomagal ukvarjati se s katerim koli članom 
določenega razreda, ki ga lahko srečamo v prihodnje, tako da nas bo nemudoma informiral o vseh bistvenih lastnostih članov razreda. Pojem splošnega spomina vzorca se lahko nanaša na skupne lastnosti entitet katere koli vrste, najsi so to fizični objekti, družbeni dogodki ali verbalni stavki.

Zdaj lahko razumemo, zakaj so med vsemi spomini prav splošni spomini ali vzorci najbolj stabilni in najmanj ranljivi na kateri koli možganski udar. To je posebej jasno, če si ogledamo učinke retrogradne amnezije. Praviloma se posledice retrogradne amnezije nanašajo predvsem na faktografsko znanje dejstev in na proceduralno znanje kako. Faktografski spomin se deli na epizodični spomin posameznih dogodkov, ki so povezani z nekim kontekstom (npr. nakup prvega avta, nastop prvega delovnega mesta), in semantični spomin, ki je shranjen neodvisno od konteksta (večina ljudi npr. ve, da je Rim glavno mesto Italije, vendar zagotovo ne ve, kdaj so znanje o tem dejstvu usvojili). Na vpliv retrogradne amnezije so najmanj občutljivi semantični spomini za splošne informacije.

Splošni spomini ne propadajo. Spomini predstavljajo vsebino naših mentalnih življenj, vendar, kot rečeno, niso vsi spomini enaki. Praviloma se splošni spomini uporabljajo pogosteje kot posebni spomini. Goldberg (2007) je primerjal tradicionalno in svojo organizacijo znanja. Po tradicionalni taksonomiji spominov delimo spomin na proceduralni in deklarativni, slednji pa se deli na semantični in epizodični. Po Goldbergovi taksonomiji spominov se spomin deli na splošni in posamični; splošni se deli na proceduralni in splošni semantični, posamični pa na epizodični in posamični semantični.

Splošni spomini so močnejši kot posamični spomini. Zaradi zelo pogoste uporabe splošni spomini zelo hitro postajajo del dolgoročnega pomnilnika. Posledica tega je, da postajajo neodvisni od subkortikalnih možganskih struktur, za katere se ve, da so ranljive na Alzheimerjevo bolezen in druge demence, ali zelo natančno povedano od neneokortikalnih možganskih struktur, saj so hipokampusi in področja, ki jih obkrožajo, del korteksa, neokorteksa pa ne.

Primera splošnih spominov sta jezik in zaznavanje višjega reda, tj. sposobnost prepoznavanja predmetov, ki tudi temelji na spominu. Za to sposobnost moramo imeti nekje $v$ naših možganih shranjen splošni spomin, ki zajema skupne značilnosti nekega razreda stvari v celoti. Imeti moramo prej oblikovane vzorce. Ko naletimo na objekt, ki vsebuje dovolj takih skupnih značilnosti, se prikliče splošni spomin, in to je približno zaznavanje predmetov.

Propad sposobnosti uporabe jezika v psihologiji imenujemo anomija, propad sposobnosti zaznavanja navadnih predmetov pa asociativna agnozija; povzročajo ju možganski udari, travmatske poškodbe možganov, demenca in nekatere druge možganske bolezni. Toda posebej pomembno je, da sta jezik in zaznavanje višjega reda odporna proti učinkom normalnega staranja, saj sta neodvisna od subkortikalnih struktur.

Znanje jezika in zaznavno znanje sta tako posebna primera človekovega mišljenja, da ju psihologi sploh ne obravnavajo kot spomine, čeprav dejansko gre za splošne spomine. Po prevladujočem terminološkem dogovoru je beseda spomin rezervirana večinoma za spomine, ki jih Goldberg imenuje posamični spomini. V skladu s tem se beseda amnezija ne uporablja za izgubo spomina pomenov besed, namesto tega se uporablja beseda anomija. Prav tako se za izgubo spomina za navadno prepoznavanje stvari ne uporablja beseda amnezija, temveč agnozija. 
Posamični spomini so odvisni tako od neokortikalnih kot tudi subkortikalnih možganskih struktur in poškodba ene od obeh vrst struktur ali stez, ki te strukture povezujejo, povzroča njihov propad. $V$ nasprotju s tem pa so splošni spomini odvisni le od neokorteksa. Ker pa popolne zaščite pred propadom ni, imajo splošni spomini nekaj nevronskih ranljivosti. To je razlog, zakaj se splošni spomini upirajo propadu zaradi staranja in učinkov demence.

Sodobne metode funkcionalnega nevrološkega slikanja (angl. neuroimaging) - fMRI (angl. functional Magnetic Resonance Imaging), PET (angl. Posytron-Emission Tomography), SPECT (angl. Single Photon Emission Computerized Tomography) in MEG (angl. MagnetoEncephaloGraphy) - so prvič v zgodovini znanosti omogočile opazovanje slike fizioloških aktivacij $v$ delujočih možganih žive osebe pri različnih mentalnih aktivnostih. Uvajanje teh metod je spremenilo obraz nevropsihologije in kognitivne nevroznanosti podobno, kot je npr. izum teleskopa dvignil raven astronomije. Uvajanje novih tehnologij (ki so jih razvili na drugih področjih) igra po navadi odločilno vlogo $v$ znanstvenem razvoju. Uporaba teh metod je omogočila odkritje dveh dodatnih mehanizmov zaščite pogosto uporabljenega znanja, ki je predstavljeno v neokorteksu; to sta širjenje vzorcev in ekspert brez prizadevanja (angl. effortless expert), ki delujeta sporazumno.

Pri širjenju vzorca s prakso, izkušnjami in ob ponavljajoči se uporabi delov možganov, predvidenih za določene motorične sposobnosti, se zaznavne in mogoče tudi kognitivne sposobnosti razširjajo in prevzemajo sosednja področja možganske skorje. Pascual-Leone in Torres (1993) sta eksperimentalno ugotovila, da je predstavitev prsta v možganih, ki se uporablja pri branju Braillove pisave, pri slepi osebi večja od predstavitve istih prstov pri slepih posameznikih, ki niso izkušeni v Braillovi pisavi. Podobno je predstavitev prstov v možganih na levi roki pri godalnih glasbenikih večja kot pri drugih ljudeh. Tako širjenje prispeva k odpornosti vzorcev proti propadanju in učinkom možganskih bolezni. V primeru švicarskega sira je rezina večja, če je večje področje lukenj ob konstantnem številu in velikosti lukenj.

Haier in sodelavci (1992) so z metodo PET proučevali metabolične potrebe možganov pri učenju. Ugotovili so, da se s pridobivanjem mojstrstva za izvajanje določene naloge metabolične potrebe nenehno zmanjšujejo.

Sodobne študije so z uporabo fMRI pri nalogah klasifikacije objektov pokazale podoben učinek - manj je več. Dobbins in sodelavci (2004) so ugotovili, da ta učinek povezuje manj zaradi izboljšane natančne analize problema in več zaradi dejstva, da se taka analiza zaobide, in sicer zaradi avtomatske uporabe naučenih odgovorov - vrsta vzorca prepoznavanja mehanizma bližnjice. Sposobnost izvajanja ekspertnih nalog z manj metaboličnih virov je velik vir zaščite pred nevrološkimi napadi na možgane.

Pomanjkanje dobave krvi v možgane je sorazmerno značilno za staranje. Pretok krvi in dobava kisika v regije možganov, ki je odvisna od zamašenih arterij ali majhnih krvnih žil, se s staranjem zmanjšuje in sposobnost izvrševanja zapletenih mentalnih nalog z zmanjšano dobavo krvi (in zmanjšano dobavo kisika $v$ možgane) predstavlja močno (seveda ne neskončno močno) zaščito pred škodljivimi učinki cerebrovaskularnih bolezni na funkcijo možganov. Kombinirani učinek širjenja vzorcev in ekspertov brez muke lahko zadošča pri delovanju zoper učinke neke degenerativne in žilne bolezni (več let oz. celo desetletje ali dva). 
Mehanizmi spomina na ravni celic so zelo zapleteni. Mnogo znanstvenikov z Goldbergom vred je prepričanih, da je oblikovanje olajšanih nevronskih stez dejanje priklica prej shranjenih informacij ali dejanje prepoznavanja določene stvari kot člana znane kategorije.

Znanost o možganih je bila tradicionalno empirična disciplina. Vendar se dozorelost neke znanosti ocenjuje po sposobnosti razvoja teoretičnih orodij. Podrobnosti, kako se spomini oblikujejo in najdejo, opisuje računalniška nevroznanost. Goldberg daje prednost poimenovanju teoretična nevroznanost, po analogiji s teoretično fiziko, saj je pridevnik računalniška ponesrečeno pohleven. Vendar je sodobna računalniška nevroznanost najbrž najstrožja veja proučevanja možganov, saj vključuje večinoma matematične modele procesov $\checkmark$ možganih. Uporaba zmogljivih računalnikov je pripeljala do razvoja hibridnih teoretičnih in eksperimentalnih metod - do računalniškega modeliranja. Teorija o strukturi nekega zapletenega biološkega sistema se nastavi kot računalniški model, nato se empirično proučuje obnašanje modela pri izvajanju različnih nalog in spreminjanju njegovih različnih parametrov. Povezanost teorije in eksperimenta prinaša koristnejše in bolj nepričakovane rezultate kakor vsaka izmed teh dveh metod posebej. Tako so spoznanja o spominu pridobljena z uporabo formalnih nevronskih mrež.

Posamični elementi mreže so nevroni. Sposobnost posamičnega nevrona je zelo omejena. Moč mreže za reševanje problemov narašča kot posledica večkratnih interakcij, sekvenčnih in paralelnih, med nevroni. Informacijska moč mreže je povsod in nikjer in je distribuirana skozi mrežo v celoti. Vsak, celo zmerno zapleten kognitivni proces, ki se odvija v realnih bioloških možganih, vključuje preveliko število nevronov in glia celic, da bi bila mogoča eksperimentalna analiza vseh pomembnih interakcij med njimi. Preprosto povedano: možgani so struktura s preveliko delov v gibanju, najzanimivejše lastnosti izvirajo iz večkratnih interakcij med deli, in ne iz samih delov. Formalne nevronske mreže osupljivo kažejo možganom podobne lastnosti. Najbolj zanimiva izmed teh lastnosti je nastanek novih sposobnosti, ki jih projektanti niso izrecno programirali $v$ model. Takim spontano nastalim sposobnostim rečemo nenadoma nastale lastnosti.

Najzanimivejše med temi lastnostmi so atraktorji ali stanja atraktorjev. Atraktor je mreža oz. skupina tesno povezanih nevronov s stabilnim vzorcem aktivnosti $v$ odsotnosti direktnih dražljajev iz zunanjega okolja. Ta stabilna stanja atraktorjev so mogoča zaradi tako močnih povezav med nevroni znotraj atraktorja, da aktivacija katere koli podmreže nevronov, celo sorazmerno zelo majhne podmreže, zadošča za poganjanje določenega vzorca v celoti.

To lastnost atraktorjev v možganih je v nevroznanost uvedel Gerald Edelman pod imenom degeneracija. Degeneracija je osnovna matematična lastnost, ki se zelo proučuje $v$ algebri in simbolični logiki, je pa zelo pomembna lastnost bioloških atraktorjev. Besedo atraktor je uvedel francoski matematik Jules-Henri Poincare za označevanje situacije, ko neka enačba prinaša posamično konstantno rešitev za celo vrsto numeričnih inputov. Taka rešitev privlači (angl. attracts) celo vrsto posebnih numeričnih inputov $v$ določeno enačbo. Drugi primer atraktorja najdemo $v$ Boolovi algebri, kjer isto logično formulo lahko ustvarimo $z$ vnosom velikega števila kombinacij.

Edelman in Gally (2001) sta prva poudarila razširjenost degeneracije v bioloških sistemih in temeljno vlogo degeneracije pri olajšanju evolucije. Podobno kot matematične enačbe $z$ lastnostmi atraktorja bo neki atraktor nevronske mreže $v$ možganih aktivirala vrsta različnih 
inputov iz zunanjega sveta, ki bo aktivirala isto mrežo. Isto nevronsko mrežo bo npr. aktiviral kratek črn kemični svinčnik, dolg rdeč kemični svinčnik in tudi zlat kemični svinčnik, ki skupaj predstavljajo različne čutilne inpute. Vsak atraktor ima zbiralnik (angl. basin), tj. mrežo podobnih vzorcev aktivnosti, ki stremijo, da se preoblikujejo $v$ stanje atraktorja. To pomeni, da se na osnovi vrste podobnih, vendar neidentičnih vzorcev aktivacije prepozna sistem, kot da so nekako ekvivalentni. Glavne lastnosti atraktorjev v formalni nevronski mreži, posebno lastnosti degeneracije, ustrezajo naklonjenosti celotnega spomina, da ga pokliče kateri koli izmed sestavnih delov. Atraktor z zbiralnikom je podoben splošnemu spominu, kjer je mnoštvo podobnih objektov prepoznano kot članstvo $v$ isti kategoriji.

Danes vemo, da krogi, podobni atraktorjem, obstajajo tudi v možganih. Njihova funkcija ni povsem jasna, vendar se nabirajo dokazi, ki podpirajo domnevo, da so atraktorji spomini. To je trdil tudi Hopfield (1982), eden izmed pionirjev modeliranja nevronskih mrež.

\section{Zaključna premišljevanja}

Ta članek je 1. del članka, ki sestoji iz dveh delov. Ta dva dela članka sta s številnimi drugimi članki del (še neobjavljene) elektronske knjige Informacijska znanost na dvosmernih mostovih: Izbor teoretičnih del iz informacijske znanosti po modelu eklektičnega dokumenta (Gerkeš, 1999). V knjigi je beseda o vzajemnem delovanju informacijske znanosti z znanostjo o znanosti, zgodovinskimi študijami, bibliografijo, dokumentacijo in knjižničarstvom, filozofijo, (meta)fiziko, pravom, sociologijo, ekonomijo, informacijsko družbo in psihologijo ter o tesni povezanosti vseh sodobnih znanosti z moderno informacijsko znanostjo in računalništvom kot uporabno epistemologijo in novo znanstveno paradigmo.

$\checkmark$ tem članku je povezanost in soodvisnost informacijske znanosti in psihologije prikazana na primeru individualne modrosti. Individualna modrost je kot človekova mentalna sposobnost ena izmed številnih psihičnih pojavov, ki so prednostno (kat egzochen) predmet znanstvenega proučevanja na področju (nevro)psihologije. Kot del informacijskega modela PIZM (podatekinformacija-znanje-modrost) je modrost predmet proučevanja na področju informacijske znanosti. Hierarhijo PIZM je prvi postavil T. S. Eliot v pesmi Skala (The Rock) leta 1934: „Where is the wisdom we have lost in knowledge? / Where is the knowledge we have lost in information?« (Kje je modrost zgubljena spričo znanja? / Kje znanje, izgubljeno ob podatkih?) (Eliot, 2003-2004, str. 13; Šercar in Brbre, 2007).

Modrost, ena izmed številnih človekovih mentalnih sposobnostih, ki jo je mogoče meriti s tovrstnimi testi, je zmogljivost uresničiti vrednote $v$ življenju zase, za druge in za splošno dobro; kot najvišjo obliko kompetentnosti jo poznajo vse velike religije oz. filozofije v verski obliki. Že starogrški zdravniki so vedeli, da so »duh« in mentalne funkcije »proizvodi« možganov.

V čestitki prijatelju ob 70. rojstnem dnevu sem zapisal: "Mlad človek se ne zaveda mladosti, saj mladost obstaja le v spominu in se je lahko spomnijo le starejši ljudje! Razen tega moramo imeti tudi čarobno geslo za odpiranje vrat preteklosti in za iskanje izgubljenega časa po spominu. Starost tudi ni slaba, če nisi hudo bolan! Katon starejši, rimski državnik, vojskovodja, govornik in pisatelj, pravi, da je napačno reči, da je starost bedna - kot piše Ciceron v spisu Cato Maior de Senectute: „Nefas esse dictu miseram fuisse talem senectutem«. Grščine se lahko učiš tudi, če si sto let star. 
V antični Šparti bi bil moj prijatelj že 10, jaz pa 20 let član sveta starešin (geruzija ${ }^{4}$ ), sestavljenega iz 28 gerontov $^{5}$, ki so poleg dveh izvoljenih kraljev ${ }^{6}$ in petih državnih nadzornikov (eforiji ${ }^{7}$ ) imeli najvišjo oblast v državi. (Šercar, 2018)

Z znanstvenega stališča je modrost kot psihični pojav in mentalna sposobnost funkcija možganov z materialnimi, anatomskimi in fiziološkimi osnovami. "Nemo Psychologus nisi Physiologus!« (Nisi psiholog, če nisi tudi fiziolog.) (Arciero et al., 2018) Stiki s telesom in jazom, z zunanjim fizičnim svetom in zunanjim svetom materialne in duhovne kulture, vključno $\mathrm{s}$ samozavedanjem, so posredovani z navidezno manj trdnimi, toda ne manj gmotnimi, mentalnimi sposobnostmi za sprejemanje, obdelavo, shranjevanje, iskanje in prenos informacij. Modrost je (med drugim) sposobnost prepoznavanja vzorcev pri reševanju problemov in odločanju. Prepoznavanje vzorcev je vrsta spomina, spomini pa so vsebina našega mentalnega življenja. Kajti spomini vzorcev so zelo odporni proti propadanju, tovrstne knjižnice se $v$ naših možganih polnijo skozi celotno življenjsko obdobje. Tako s staranjem narašča tudi sposobnost prepoznavanja vzorcev oz. modrost. Potemtakem je staranje cena modrosti. S staranjem je sicer povezano nevrološko upadanje (senilnost, demence), vendar pa s staranjem narašča tudi modrost. Gre za paradoks modrosti, ki ga je odkril in poimenoval ameriški nevropsiholog latvijsko-judovskega porekla Elkhonon Goldberg (2007). S staranjem možganov pod določenimi pogoji postaja naš duh vedno močnejši. Eden izmed pogojev tega paradoksa poleg normalnega poteka staranja je vsekakor redno vsakodnevno aktivno mentalno življenje, ki preoblikuje možgane tako, da jih ščiti pred biološkim razdejanjem.

Mehanizmi prepoznavanja vzorcev predstavljajo avtentično psihološko realnost in niso izrazi iz logike. Spomin se oblikuje in shranjuje $v$ možganskih strukturah, ki prejemajo in obdelujejo nove informacije. Spomine delimo na splošne in posamične, splošne na proceduralne in splošne semantične, posamične pa na epizodične in posamične semantične. Splošni spomini so spomini vzorcev in so močnejši kot posamični spomini. Vzorec, shranjen $v$ spominu možganov, deluje kot privlačevalec (atraktor), tako da tudi majhne mreže nevronov samodejno vzbudijo isto spominsko stanje, in to v celoti. Že po prvih kadrih nekega filma vemo, ali smo ga že gledali. Učenje je ponavljajoče se nalaganje vzorcev na nevronske mreže. Zadosti močan vzorec ima lahko dosmrten rok trajanja, če se z učenjem moč vzorca obnavlja, sicer naučeni vzorci s časom propadejo, za razliko od gensko podedovanih vzorcev.

Mentalno vitalnost stereotipno povezujemo z mladostjo, mentalni upad s starostjo.

Modrost je zadnji (od 65. leta starosti do smrti) izmed osmih stadijev v psihosocialnem razvoju. Povezana je z ekologijo znanja, in če je ta ne vključuje, je uporaba znanja slepa.

Načrtovana e-knjiga Informacijska znanost na dvosmernih mostovih: izbor teoretičnih del iz informacijske znanosti je nastala po tentativnem načrtu, ki sem ga zastavil pred desetimi leti.

\footnotetext{
${ }^{4}$ Geruzijo je uvedel Likurg (900-800 pr. n. š.), špartanski zakonodajalec, oče špartanske države, ki je bil tudi seksist, po njegovem so ženske dobre le kot kariatide.

${ }^{5}$ Geronti, starci, najmodrejši državljani, stari nad 60 let, izvoljeni dosmrtno.

${ }^{6}$ Basileus, kralj, najpogumnejši državljan.

7 Eforiji so najpametnejši državljani, starejši od 30 let, izvoljeni vsako leto, a le enkrat v življenju; vrhovni sodniki, ki so preganjali nezaželene tujce; imeli so pravico do kaznovanja in nadzorovanja kraljev, da se demokracija ne bi prelevila v tiranijo, napovedovali so vojne in sklepali mir.
} 
Načrt je bil po eni strani zadosti odprt, da ni oviral vsebinske razsežnosti, in po drugi strani hkrati določen do stopnje, ki je preprečevala možna večja odstopanja od glavne smeri.

\section{Zahvala}

Avtor se zahvaljuje kolegici Andreji Avberšek, dr. med. in spec. nevrologije, zaposleni na Institutu za nevrologijo Univerzitetnega kolidža v Londonu (Institute of Neurology, University College London), za prispevek k osvetlitvi nekaterih problemov s strani klinične nevrološke prakse.

\section{Reference}

Arciero, G. et al., 2018. "Nemo psychologus nisi physiologus". V: Arciero, G., Bondolfi, G. in Mazzola, V., The foundations of phenomenological psychotherapy. Cham: Springer. Str. 5370.

Behnud, 1953. Uvod: Berzevejhovo putovanje u Indiju. V: Kelila i Dimna (Pančatantra): stare indiske pripovijetke. Sarajevo: Svjetlost. Str. 1-35, 28.

Berlyne, D. E., 1960. Conflict, arousal and curiosity. New York: McGraw-Hill.

Biblija.net - Sveto pismo na internetu, Stara zaveza, 2020. Dostopno na: http://www.biblija.net/biblija.cgi?lang=sl [12. 12. 2021].

Binet, A., 1903. L'étude expérimentale de l'intelligence. Paris: Schleicher.

Bouton, K., 2011. Books of the times: if cave men told jokes, would humans laugh? New York Times, str. 3. Dostopno na: https://www.nytimes.com/2011/12/28/books/how-to-think-likea-neandertal-by-thomas-wynn-and-frederick-l-coolidge-review.html [12. 12. 2020].

Bruner, J., Goodnow, J. J. in Austin, G. A., 1956. A study of thinking. New York: Wiley.

Chang, L., 2006. Wisdom for the soul: five millennia of prescriptions for spiritual healing. Washington: Gnosophia.

Claparède, E., 1933. La genèse de I'hypothèse: étude expérimentale. Arch. Psychol., 24, str. 1-155.

Dobbins, I. G. et al., 2004. Cortical activity reductions during repetition priming can result from rapid respons learning. Nature, 428(6980), str. 316-319.

Edelman, G. M. in Gally, J., 2001. Degeneracy and complexity in biological systems. Proceedings of the National Academy of Sciences, USA., 98(24), str. 13763-13768.

Edelman G. M. in Tononi G., 2000. A universe of consciousness: how matter becomes imagination. New York: Basic Books.

Eisenberger, N. I., Lieberman, M.D. in Williams, K. D., 2003. Does rejection hurt? An fMRI study of social exclusion. Science, 302(5643), str. 290-292.

Eliot, T. S., 2003-2004. Zbrana dramska dela. Celje: Mohorjeva družba.

Erikson, E., 1968. Identity: youth and crisis. New York: Norton. 
Floridi, L., 2002. What is the philosophy of information? Meta philosophy, 33(1-2), str. 123145. Dostopno na: https://onlinelibrary.wiley.com/doi/abs/10.1111/1467-9973.00221 [12. 12. 2020].

Fuster, J. M., 2003. Cortex and mind: unifying cognition. New York: Oxford University Press. Gerkeš, M., 1999. Kakovost informacij na WWW in eklektični dokumenti. Cobiss obvestila, 4(1), str. 14-23. Dostopno na: https://cobiss.si/oz/HTML/CO letnik 4 final/14/index.html [12. 12. 2020].

Goldberg, E., 2007. The wisdom paradox: how your mind can grow stronger as your brain grows older. London: Pocket Books.

Haier, R. J. et al., 1992. Regional glucose metabolic changes after learning a complex visuospatial/motor task: a positron emission tomographic study. Brain Res, 570(1-2), str. 134-143.

Hark, M., 2004. Popper, Otto Selz and the rise of evolutionary epistemology. Cambridge: University Press.

Heidegger, M., 1997. Bit in čas. Ljubljana: Slovenska matica.

Hopfield, J. J., 1982. Neural networks and physical systems with emergent collective computational abilities. Proceedings at Natl Acad Sci USA, 79(8), 2554-2558.

Hughlings Jackson, J., 1884. On affectations of speech from disease of the brain (2). Brit Med J, 12, str. 703-7.

Inhelder, B., 1969. Memory and intelligence in the child. V: Elkind, D. in Flavell, J. H. ur. Studies in cognitive development: essays in honor of Jean Piaget. New York: Oxford University Press. Str. 337-364.

Luria, A. R., 1966. Higher cortical functions in man. Boston: Springer.

Mackay, C., 1841. Extraordinary popular delusions and the madness of crowds. New York: Farrar, Straus and Giroux.

Mandić, O., 1969. Leksikon judaizma i kršćanstva. Zagreb: Matica hrvatska.

Maslow, A. H., 1943. A theory of human motivation. Psychological Review, 50, str. 370-396. Dostopno na: http://psychclassics.yorku.ca/Maslow/motivation.htm [12. 12. 2020].

Paradise, M., Cooper, C. in Livingston, G., 2009. Systematic review of the effect of education on survival in Alzheimer's disease. Int Psychogeriatr, 21(1), str. 25-32.

Pascual-Leone, A. in Torres, F., 1993. Plasticity of the sensorimotor Cortex representation of the reading finger in Braille readers. Brain, 116(1), str. 39-52.

Pijaže, Ž., 1988. Odnos govora i mišljenja s genetičkog stanovišta. V: Pijaže, Ž. in Inhelder, B. Intelektualni razvoj deteta - izabrani radovi. Beograd: Zavod za udžbenike i nastavna sredstva. Str. 183-190. 
Pijaže, Ž. in Inhelder, B., 1988. Intelektualne operacije i njihov razvoj. V: Pijaže, Ž. in Inhelder, B. Intelektualni razvoj deteta - izabrani radovi. Beograd: Zavod za udžbenike i nastavna sredstva. Str. 73-120.

Platon, 1996. Fedar ili O Lepoti, 2. Šta se iziskuje od pisanja beseda s obzirom na umetnost, LIX. Dostopno na: https://tesla.rcub.bg.ac.rs/ mrsasha/tekstovi/fedar.html [12. 12. 2020].

Popper, K. R., 1994. Knowledge and the body-mind problem: in defence of interaction. London, New York: Routledge.

Selz, O., 1913, 1922. Über die Gesetze des geordneten Denkverlaufs. Stuttgart: W. Spemann

Selz, O., 1924. Die Gesetze der produktiven und reproduktiven Geistestätigkeit. Bonn.

Friedrich Cohen.

Shannon, C. E. in Weaver, W., 1949. The mathematical theory of communication. Urbana: University of Illinois Press.

Simon, H. 1996. The science of the artificial. 3rd ed. Cambridge: MIT Press. Dostopno na: https://monoskop.org/images/9/9c/Simon Herbert A The Sciences of the Artificial 3rd ed.pdf [12. 12. 2020].

Snyder, A. et al., 2003. Savant-like skills exposed in normal people by suppressing left frontotemporal lobe. Journal of Intergrative Neuroscience, 2(2), str. 149-58.

Spearman, C., 1923. The nature of intelligence. London: Macmillan.

Šercar, T. M., 2006. Filozofija bibliotekarstva in informacijske znanosti: ali sta bibliotekarstvo in informacijska znanost $v$ filozofiji informacij dokončno pridobila ustrezen teoretični dom? Organizacija znanja, 11(3), str. 75-80. Dostopno na:

http://home.izum.si/cobiss/OZ/2006 3/Html/clanek 03.html [12. 12. 2020].

Šercar, T. M., 2018. Pismo prijatelju. Locutio, 204. Dostopno na:

https://www.locutio.si/avtorji.php?ID=341\&clanek=3353 [12. 12. 2020].

Šercar, T. M. in Brbre, I., 2007. Prispevek k filozofiji knjižničarstva in informacijske znanosti. Organizacija znanja, 12(3), str. 119-136. Dostopno na:

https://www.cobiss.si/oz/HTML/OZ 20073 final/22/ [12. 12. 2020].

Šercar, T. M. in Trojar, V., 2009. Modrost kot predmet informacijske znanosti. Organizacija znanja, 14(3), str. 62-80. Dostopno na:

https://www.cobiss.si/oz/HTML/OZ 20093 final/18/index.html [12. 12. 2020].

Vajt, J. G., 1985. Velika borba između Hrista i Sotone. Nastanak velikog sukoba u hrišćanskoj eri. 2. izd. Beograd: Unija pokreta adventista sedmog dana.

Vygotsky, L. in Luria, A., 1930. Tool and symbol in child development. Dostopno na: https://www.marxists.org/archive/vygotsky/works/1934/tool-symbol.htm [12. 12. 2020].

Weininger, O., 1903. Geschlecht und Charakter. Wien, Leipzig: Wilhelm Braumüller.

Wertheimer, M., 1945. Productive thinking. New York: Harper. 
Wynn, T. in Coolidge, F. L., 2011. The implications of the working memory model for the evolution of modern cognition. Int J Evol Biol., 2011: 741357. Dostopno na:

10.4061/2011/741357 [12. 12. 2020].

Zgonik, S., 2013. Intervju: Dr. Maja Bresnajac. Mladina, 28, 12. julij 2013, str. 39-42. 